\title{
FE675
}

\section{Economic Impacts of the Florida Environmental Horticulture Industry in $2005^{1}$}

\author{
Sponsored Project Report to the Florida Nursery, Growers and Landscape Association
}

Alan W. Hodges and John J. Haydu²
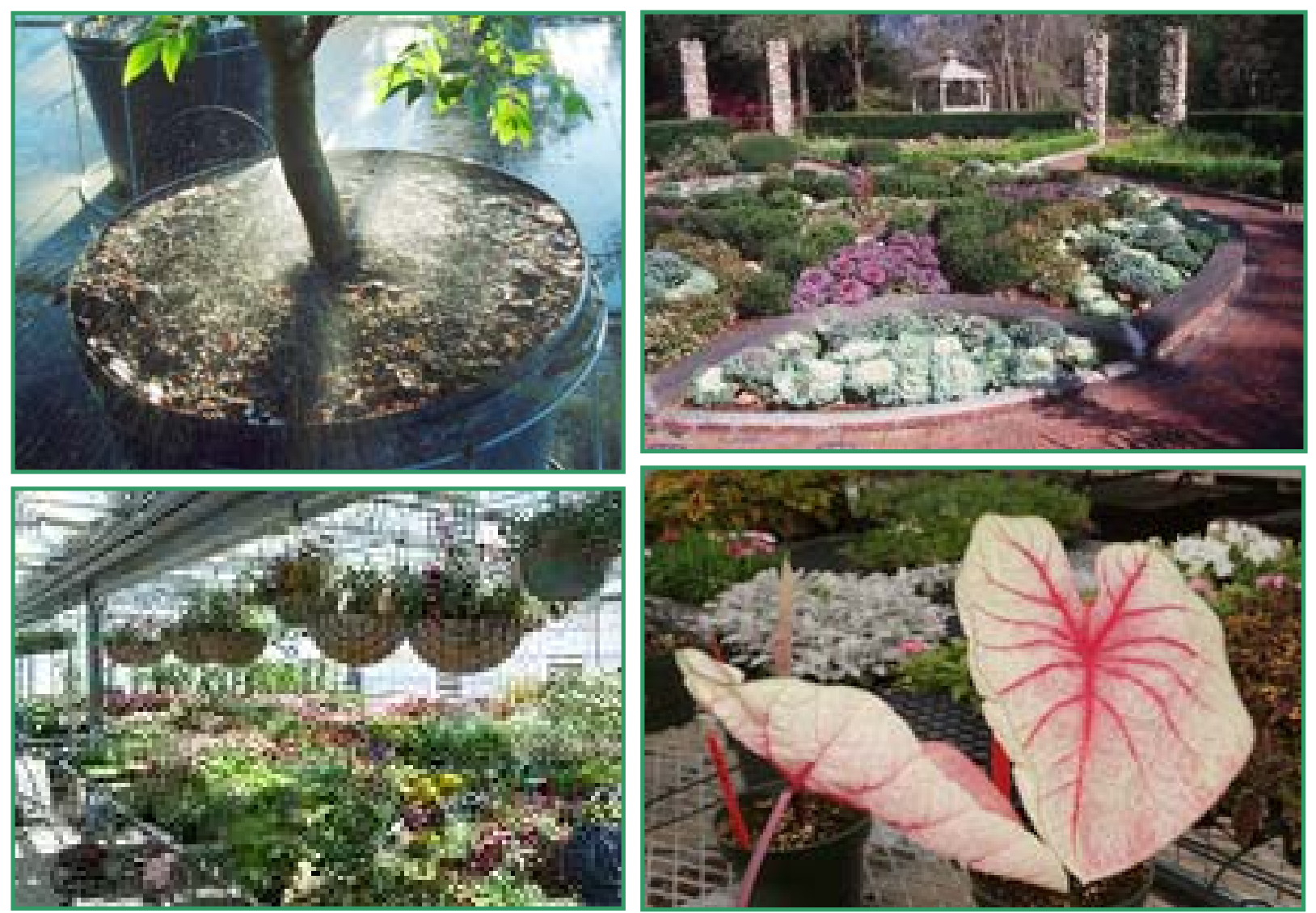

\section{UF $\mid$ FLORIVRIDA \\ IFAS Extension}

\begin{abstract}
${ }^{1}$ This is EDIS document FE675, a publication of the Food and Resource Economics Department, Florida Cooperative Extension Service, Institute of Food and Agricultural Sciences, University of Florida, Gainesville, FL. Published October 2006. Please visit the EDIS website at http://edis.ifas.ufl.edu.

${ }^{2}$ Alan W. Hodges, Associate In, Food and Resource Economics Department, University of Florida, Gainesville, FL; and John J. Haydu, Professor, Food and Resource Economics Department, Mid-Florida Research and Education Center, Apopka, FL, Florida Cooperative Extension Service, Institute of Food Agricultural Sciences, University of Florida, Gainesville, FL.
\end{abstract}

The Institute of Food and Agricultural Sciences (IFAS) is an Equal Opportunity Institution authorized to provide research, educational information, and other services only to individuals and institutions that function with non-discrimination with respect to race, creed, color, religion, age, disability, sex, sexual orientation, marital status, national origin, political opinions, or affiliations. U.S. Department of Agriculture, Cooperative Extension Service, University of Florida, IFAS, Florida A\&M University Cooperative Extension Program, and Boards of County Commissioners. Larry Arrington, Dean. 


\title{
Economic Impacts of the Florida Environmental Horticulture Industry in 2005
}

\section{Sponsored Project Report to the Florida Nursery, Growers and Landscape Association}

\author{
Alan W. Hodges, PhD, Associate, and John J. Haydu, PhD, Professor \\ University of Florida, Institute of Food and Agricultural Sciences \\ Food \& Resource Economics Department, Gainesville, FL, \\ and Mid-Florida Research and Education Center, Apopka, FL \\ Telephone: 352-392-1881 x312; 407-884-2034 x156 \\ Email: awhodges@ufl.edu; jjh@ifas.ufl.edu \\ Report available at http://economicimpact.ifas.ufl.edu
}

Revised September 29, 2006

\section{Table of Contents}

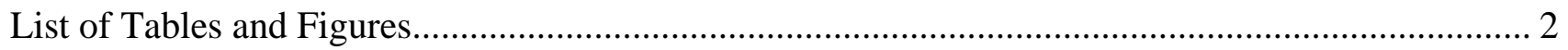

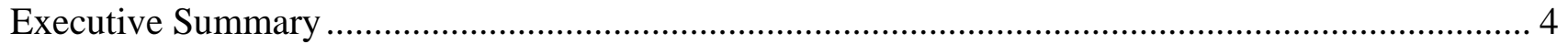

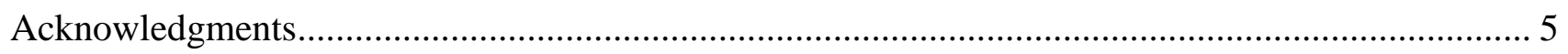

Introduction: The Florida Environmental Horticulture Industry ................................................. 6

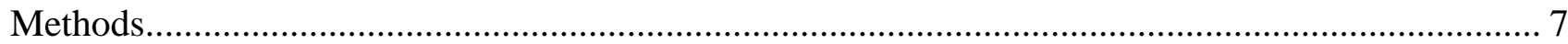

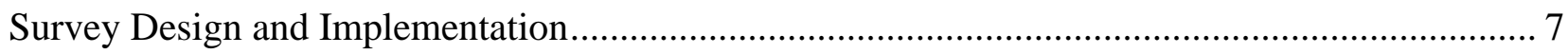

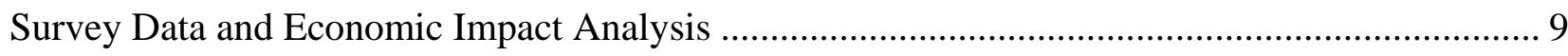

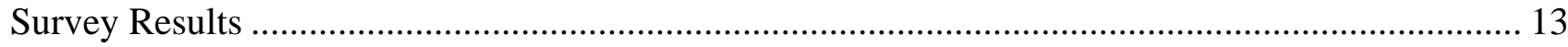

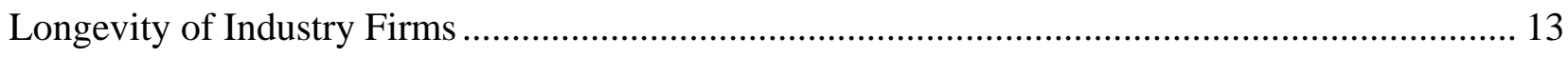

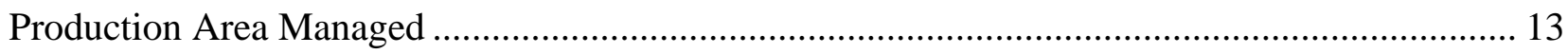

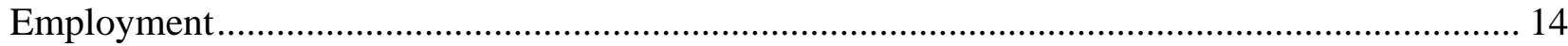

Sales of Environmental Horticultural Products and Services ................................................ 15

Market Channels and Practices for Horticultural Products ................................................... 17

Impacts of Hurricanes on the Environmental Horticulture Industry in 2004 and 2005 ............... 20

Issues and Threats to the Environmental Horticulture Industry ............................................... 22

Financial Borrowing Characteristics and Needs for Wholesale Nurseries ................................. 23

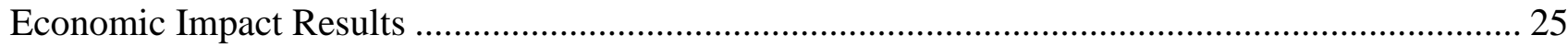

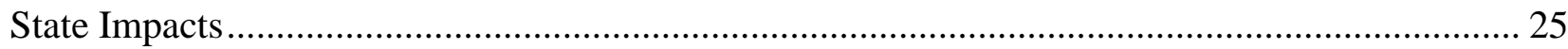

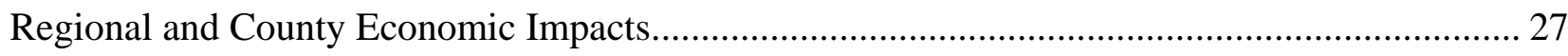

Impacts on Allied Suppliers for Nursery Producers ............................................................ 33

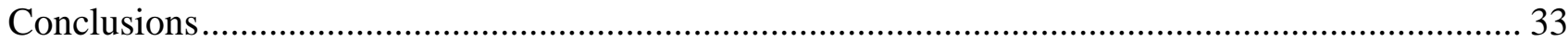




\section{List of Tables and Figures}

Figure 1. Value of Florida nursery and greenhouse crops, 1995-2004..................................... 6

Table 1. Number of survey respondents by industry sector and Florida county. ............................ 8

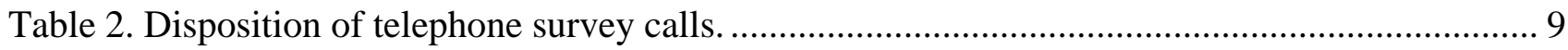

Table 3. Survey sample size and expansion factors......................................................... 10

Table 4. Economic multipliers for the environmental horticulture industry sectors in Florida......... 10

Table 5. Reported employment and wages paid in the environmental horticulture industry, by

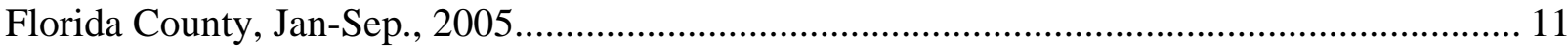

Figure 2. Years in business reported by survey respondents. ............................................... 13

Figure 3. Greenhouse or shadehouse area reported by survey respondents. ................................. 13

Figure 4. Container and field nursery area reported by survey respondents. ............................... 14

Table 6. Nursery production area reported...................................................................... 14

Table 7. Employment in the Florida environmental horticulture industry, 2005.......................... 14

Figure 5. Distribution of respondents by annual sales class ...................................................... 15

Table 8. Sales reported by survey respondents and estimated total industry sales, 2005................. 15

Figure 6. Distribution of nursery sales by market region. ................................................. 16

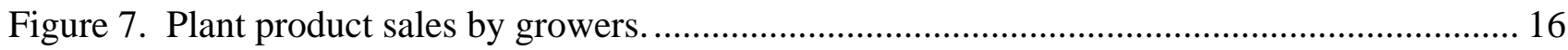

Table 9. Sales of specific types of horticultural products and services ..................................... 17

Figure 8. Distribution of nursery product sales by type of customer....................................... 18

Figure 9. Distribution of landscape service sales by type of customer........................................ 18

Figure 10. Distribution of retail horticultural product sales by type of customer............................ 18

Figure 11. Markets for nursery products identified as expanding by survey respondents. .............. 19

Figure 12. Marketing practices used by firms surveyed......................................................... 19

Figure 13. Industry firms directly affected by named hurricanes in 2004 and 2005....................... 20

Table 10. Estimated total losses due to hurricanes in 2004 and 2005. ......................................... 20 


\section{List of Tables and Figures (continued)}

Figure 14. Distribution of product losses due to hurricanes in 2004 and 2005. ............................ 21

Figure 15. Distribution of structural damages due to hurricanes in 2004 and 2005........................ 21

Figure 16. Distribution of cleanup costs due to hurricanes in 2004 and 2005.............................. 21

Figure 17. Distribution of length of business interruption due to hurricanes in 2004 and 2005....... 22

Figure 18. Issues rated as "very important” by survey respondents.......................................... 22

Table 11. Nursery financial borrowing characteristics and credit needs..................................... 24

Table 12. Summary of economic impacts of the environmental horticulture industry in Florida, 2005

Figure 19. Trend in value added impacts of the Florida environmental horticulture industry: 1997 to 2005.

Table 13. Economic impacts of the Florida environmental horticulture industry in 1997, 2000 and 2005.

Figure 20. Employment impacts of the environmental horticulture industry in the top 20 Florida counties, 2005.

Table 14. Sales and output impacts of the environmental horticulture industry in Florida counties, 2005.

Table 15. Employment and value added impacts of the environmental horticulture industry in Florida counties. 30

Figure 21 Map of economic regions of Florida.

Figure 22. Employment impacts of the environmental horticulture industry in Florida regions, 2005.

Table 16. Regional economic impacts of the environmental horticulture industry in Florida, 2005. 32

Table 17. Estimated purchases of supplies by the nursery and greenhouse industry in Florida, 2005 


\section{Executive Summary}

The economic impacts of the environmental horticulture industry in Florida in 2005 were evaluated and compared with results from previous studies done for 1997 and 2000. Telephone and internet surveys were conducted with over 800 industry firms, including wholesale nurseries, landscape services and horticultural retailers.

Based on expanded survey results and other secondary data, total industry sales in 2005 were estimated at \$15.24 billion (Bn). Total industry output amounted to \$10.39 Bn, with \$3.01 Bn for wholesale nurseries, \$5.25 Bn for landscape services, and \$2.13 Bn for horticultural retailers, which reflects the average gross margin on retail sales. Direct employment in the industry was 190,000 fulltime jobs, plus nearly 104,000 temporary, part-time or seasonal jobs.

Economic impacts were estimated with multipliers from a regional input-output model for Florida developed using the Implan software. Multiplier effects capture activity in other sectors of the Florida economy in the industry supply chain (indirect effects) and spending by employee households (induced impacts). Total employment impacts were 319,000 fulltime and part-time/seasonal jobs, including 24,000 jobs created in other sectors of the Florida economy. Total value added impacts of \$8.65 Bn included \$5.19 $\mathrm{Bn}$ in labor income for employee wages, salaries, and business owner (proprietor) income. Fiscal impacts included \$549 million (Mn) in indirect business taxes paid to local, state, and federal governments. Since the previous study for the year 2000, total employment impacts increased by 131,000 jobs, or an average annual compound rate of 11.1 percent, while output impacts increased by \$2.4 Bn, or 4.2 percent annually.

Estimates of industry sales, employment and economic impacts were developed separately for all 67 Florida counties and nine regions anchored by the major metropolitan areas, based on their share of total statewide direct employment. Total employment impacts were highest in the counties of Miami-Dade (40,837 jobs), Palm Beach (23,776), Orange (21,733), Hillsborough (20,410), Broward (18,157), Duval $(11,768)$, Volusia $(10,454)$, Pinellas $(10,208)$, Lee $(10,162)$, Lake $(9,814)$, Polk $(9,532)$, Collier $(9,030)$, and Seminole $(9,031)$. Regional employment impacts were highest in the Miami-Ft Lauderdale region (95,202 jobs), followed by Orlando (86,157), Tampa-St. Petersburg (37,711), Sarasota-Bradenton (35,541), Jacksonville $(22,580)$, Tallahassee $(13,515)$, Gainesville $(12,315)$, Pensacola $(11,839)$, and Panama City $(3,713)$.

Nursery growers reported managing a total area of 82,440 acres in container, field and greenhouse production systems. About $\$ 1.27 \mathrm{Bn}$ or 42 percent of nursery sales were to markets outside the state, including other southeast states (14\%), the northeast (12\%), midwest (8\%), west (6\%), Canada (1\%) and other foreign countries (1\%). The most important plant products were shrubs, representing \$578 Mn or 19 percent of sales, followed by tropical foliage ( $\$ 437 \mathrm{Mn}, 17 \%)$, deciduous trees (\$389 Mn, 15\%), turfgrass (\$307 Mn, $10 \%$ ), liners (\$297 Mn, 10\%), potted flowering plants (\$281 Mn, 9\%) and palms (\$220 Mn, 7\%). Deciduous, evergreen and flowering trees together represented $\$ 670 \mathrm{Mn}$ or 22 percent of nursery sales. Florida native plants represented about 11 percent of nursery sales. In the landscape services sector, 47 percent of sales were for landscape installation, 30 percent for landscape maintenance, 10 percent for design (landscape architecture), and 14 percent for other services. In the horticultural retailing sector, 40 percent of sales were for live plants, 31 percent for horticultural supplies, 11 percent for hard goods, and 19 percent for miscellaneous other goods.

Finally, the study evaluated the impacts on the horticulture industry from eight named hurricanes that struck Florida during 2004 and 2005. Some 79 percent of surveyed firms were adversely impacted by at least one hurricane. Total damages and losses due to hurricanes were estimated at $\$ 2.12$ billion, including product (crop) losses of \$1.05 Bn, structural damages of \$465 Mn and cleanup costs of \$605 Mn. Product losses of at least $\$ 100,000$ were sustained by 22 percent of firms, while structural damages and cleanup costs of this level were suffered by 12 percent and 8 percent of firms, respectively. Nearly half (48\%) of firms had their business interrupted for 3 weeks or more.

Keywords: Florida, environmental horticulture, economic impact, multipliers, output, employment, value added, Implan, economic region, wholesale plant nurseries, landscape services, horticultural retailers, marketing, hurricanes. 


\section{Acknowledgments}

This research project was sponsored by the Florida Nursery, Growers and Landscape Association (FNGLA), Orlando, Florida, under the leadership of Ben Bolusky, Executive Vice President, and with the support of FNGLA member chapters: Action Chapter, Central East Coast Chapter, Coastal Springs Chapter, Frontrunners Chapter, Highlands Heartland Chapter, Lake Region Chapter, Miami-Dade Chapter, Royal Palm Chapter, Treasure Coast Chapter. Financial support was also provided by Tampa Bay Wholesale Growers, AgFirst/Farm Credit Bank and Farm Credit Associations of Florida. Development of internet surveys was assisted by Mohammad Rahmani (UF/IFAS). The telephone surveys were supervised by Chris McCarty and Scott Richards of the University of Florida, Bureau of Economic and Business Research. Critical reviews of this report were provided by David Mulkey and Tom Stevens (UF/IFAS). Finally, the estimates of industry values developed in this report were made possible by the hundreds of professional managers in the Florida Green industry who responded to the internet and telephone surveys. 


\section{Introduction: The Florida Environmental Horticulture Industry}

The environmental horticulture or "Green" industry encompasses a wide range of businesses, including wholesale nursery and greenhouse producers, lawn and garden supplies and equipment manufacturing and wholesale trade, landscape design, installation and maintenance services, lawn and garden stores, and other retail establishments selling plants and related lawn and garden goods. In terms of overall industry value, Florida is a leading state, ranked second only to California in the U.S. According to a recent study $^{1}$ for 2002, Florida's Green industry had total employment impacts of 147,795 jobs, output impacts of $\$ 10.0$ billion $(\mathrm{Bn})$ and value added impacts of $\$ 7.1 \mathrm{Bn}$. These results represented significant increases in Florida since previous studies done for 1997 and $2000^{2}$.

Nursery plants are one of the largest agricultural commodity groups in Florida, along with fruits, vegetables and forest products ${ }^{3}$. According to the Census of Agriculture for 2002, the state of Florida had over 4,500 commercial nursery and greenhouse farms, with production area of 119,000 acres in the open, and 361 million square feet under glass or other protective cover, total sales of $\$ 1.82 \mathrm{Bn}$, and capital assets in land, buildings and equipment averaging $\$ 610,000$ per farm ${ }^{4}$. According to official USDA time series statistics $^{5}$, Florida nursery and greenhouse sales over the past decade have grown by 25 percent in inflationadjusted terms, representing a compound annual growth rate of 2.5 percent (Figure 1).

The present study was undertaken to evaluate the economic impacts of the environmental horticulture industry in Florida for 2005, using methods similar to those employed in previous studies in order to facilitate comparisons of growth over time.

Figure 1. Value of Florida nursery and greenhouse crops, 1995-2004.

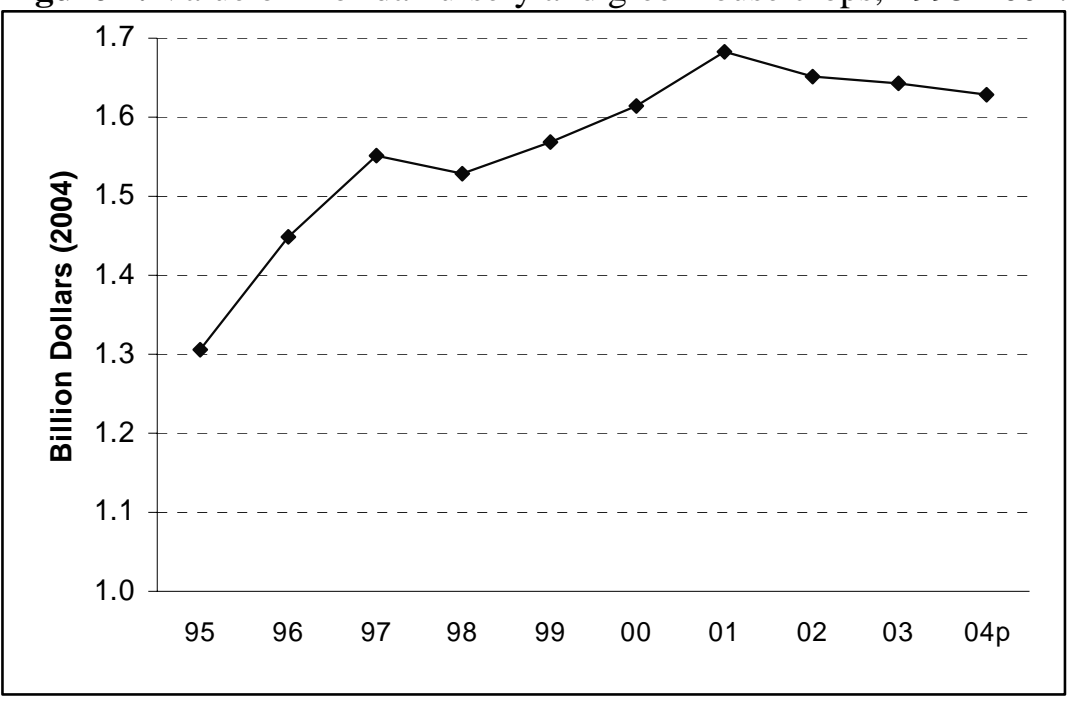

${ }^{1}$ Hall, Charles R., Alan W. Hodges, and John J Haydu. Economic Impacts of the Green Industry in the United States. Hort Technology, vol 16(2), pp 345-353, Apr.-Jun 2006. Report and executive summary available at http://economicimpact.ifas.ufl.edu.

${ }^{2}$ Hodges, Alan W. and John J. Haydu. Economic Impacts of the Florida Environmental Horticulture Industry, 2000. University of Florida/IFAS, Food \& Resource Economics Department, Economic Information Report EI02-3, Apr. 2002. Available at http://economicimpact.ifas.ufl.edu.

${ }^{3}$ Hodges, Alan W. and W. David Mulkey. Economic Impacts of Agriculture and Natural Resource Industries in Florida 2003. Extension document FE627, University of Florida/IFAS, Gainesville, Feb. 2006. Available at http://edis.ifas.ufl.edu/fe627.

${ }^{4}$ U.S. Department of Agriculture-National Agricultural Statistics Service (USDA-NASS). Census of Agriculture, 2002. Florida State and County Data, vol. 1, Geographic Area Series, Part 9, AC-02-A-9. Washington, D.C., June 2004.

5 Jerardo, A. Floriculture and Nursery Crops Situation and Outlook. FLO-2005, USDA-ERS, Washington, DC, June 2005. 


\section{Methods}

\section{Survey Design and Implementation}

Estimation of the economic value of Florida's environmental horticultural industry was based upon information obtained from telephone and internet surveys of nursery producers, landscape service firms or horticultural retailers conducted in late 2005 and early 2006. Information was collected on annual sales, employment, types of goods or services offered, state and regional trade, types of customers or market outlets, marketing practices used, and threats to the industry. All survey information concerned business results for 2005. Information on annual sales was collected in terms of ranges of values, to avoid disclosure of sensitive data. As a special issue for this survey, information was gathered on the effects of hurricanes in 2004-05, in terms of crop losses, building and equipment damages, repair/cleanup costs, and length of business interruption. In addition, information was collected on production area, and credit/finance needs for the nursery sector. Several open-ended questions were presented to gather statements by respondents in their own words regarding the impacts of their business and issues in the industry.

An internet survey of the members of the Florida Nursery, Growers and Landscape Association (FNGLA) was conducted from Dec. 1, 2005 to Jan. 23, 2006. Each FNGLA member firm was assigned to the appropriate survey group based on their primary activity. FNGLA members were contacted by email, and provided with an electronic link to the online survey. A reminder message was sent to firms that had not responded to the survey after the first two weeks. Respondents were able to return to the survey to finish or modify answers until the survey was closed. The internet survey was conducted using an online service that automatically administers the survey, tracks respondents and records responses (www.SurveyMonkey.com).

A separate telephone survey of the general business population was conducted during March and April, 2006. The telephone interviews were done under subcontract by the University of Florida, Bureau of Economic and Business Research, using a computer-assisted system to dial telephone numbers, generate questions in the proper sequence, and record respondents' answers, as well as information on interview time/date and the disposition of all calls. Firms contacted for this survey were drawn in random order from the population lists. A copy of the telephone survey questionnaire is provided in the Appendix. All firms participating in the survey were qualified as having produced or sold ornamental plants, landscape services or horticultural goods in 2005, and the individual respondent was qualified as being knowledgeable about the general business practices and management of the company. In some cases, when a qualified respondent was not available, the interviewers arranged to call back at another time. FNGLA member firms that had previously responded to the internet survey were excluded from the telephone survey to avoid duplication.

Listings of firms for the telephone survey were obtained from a variety of sources. For nurseries and horticultural retailers, a list of firms was obtained from the Florida Department of Agriculture, Division of Plant Industry. All firms in Florida that produce or sell plant products are legally required to register with this agency. The eligible population of nursery firms was considered to be those firms which were indicated as "wholesale" or "wholesale and retail" operations, and had plant inventory of at least 1,000 units. A listing of Florida landscape services businesses was obtained from a Dun and Bradstreet database, in which firms were selected based on their Standard Industrial Classification (SIC) codes for landscape counseling and planning (0781), lawn and garden services (0782), and ornamental shrub and tree services (0783). The list of firms for both surveys included 4,477 nurseries, 7,359 retailers (stock dealers) and 8,440 landscape services firms. For the internet survey, a total of 907 FNGLA member firms were targeted.

A total of 838 firms responded to the surveys, including 434 nurseries, 191 landscape service firms, and 213 horticultural retailers (Table 1). Responses to the internet survey were received from 250 firms, while 588 firms responded to the telephone surveys. A total of 6,917 telephone calls were attempted for the survey, of which 8.5 percent were completed or partially completed, 11.8 percent were refused, 22.5 percent had no answer, busy signal, answering machine, technical problems, or a qualified respondent was not available (Table 2). Some 57.2 percent of firms called were disqualified for the survey due to non-working numbers, fax lines, number changed, no eligible respondent, etc. 
Table 1. Number of survey respondents by industry sector and Florida county.

\begin{tabular}{|c|c|c|c|c|}
\hline County & Nursery & Landscape & Retail & Total \\
\hline Alachua & 13 & 5 & 5 & 23 \\
\hline Bay & 1 & 2 & 1 & 4 \\
\hline Brevard & 3 & 3 & 3 & 9 \\
\hline Broward & 21 & 13 & 12 & 46 \\
\hline Calhoun & 1 & & & 1 \\
\hline Charlotte & 3 & 1 & & 4 \\
\hline Citrus & 4 & 1 & 4 & 9 \\
\hline Clay & 4 & 2 & 2 & 8 \\
\hline Collier & 7 & 2 & 1 & 10 \\
\hline Columbia & 1 & & & 1 \\
\hline De Soto & 3 & 1 & & 4 \\
\hline Dixie & & & 2 & 2 \\
\hline Duval & 7 & 10 & 8 & 25 \\
\hline Escambia & 1 & 4 & 6 & 11 \\
\hline Flagler & & 2 & 2 & 4 \\
\hline Gadsden & 1 & & 1 & 2 \\
\hline Glades & 1 & & & 1 \\
\hline Hamilton & 1 & & & 1 \\
\hline Hardee & 4 & 1 & & 5 \\
\hline Hendry & 1 & & 2 & 3 \\
\hline Hernando & 4 & 1 & 3 & 8 \\
\hline Highlands & 11 & 2 & 1 & 14 \\
\hline Hillsborough & 23 & 6 & 14 & 43 \\
\hline Indian River & 3 & & 1 & 4 \\
\hline Jackson & & & 1 & 1 \\
\hline Jefferson & 5 & & 2 & 7 \\
\hline Lafayette & 1 & & & 1 \\
\hline Lake & 25 & 3 & 12 & 40 \\
\hline Lee & 3 & 5 & 7 & 15 \\
\hline Leon & 3 & 1 & 4 & 8 \\
\hline Levy & 3 & & 1 & 4 \\
\hline Madison & 1 & & & 1 \\
\hline Manatee & 8 & 2 & 2 & 12 \\
\hline Marion & 14 & 6 & 7 & 27 \\
\hline Martin & 5 & & 1 & 6 \\
\hline Miami-Dade & 77 & 8 & 13 & 98 \\
\hline Monroe & 4 & 6 & & 10 \\
\hline Nassau & & 1 & 3 & 4 \\
\hline Okaloosa & 1 & 1 & 7 & 9 \\
\hline Okeechobee & 4 & 1 & & 5 \\
\hline Orange & 51 & 16 & 7 & 74 \\
\hline Osceola & 1 & 2 & 1 & 4 \\
\hline Palm Beach & 39 & 25 & 14 & 78 \\
\hline Pasco & 5 & 3 & 7 & 15 \\
\hline Pinellas & 4 & 14 & 15 & 33 \\
\hline Polk & 14 & 6 & 4 & 24 \\
\hline Putnam & 3 & 1 & 1 & 5 \\
\hline Santa Rosa & 2 & & 3 & 5 \\
\hline Sarasota & 5 & 12 & 7 & 24 \\
\hline Seminole & 7 & 7 & 14 & 28 \\
\hline St. Johns & 4 & 1 & 2 & 7 \\
\hline St. Lucie & 3 & 3 & 2 & 8 \\
\hline Sumter & 5 & & & 5 \\
\hline Suwannee & 1 & & & 1 \\
\hline Volusia & 10 & 7 & 6 & 23 \\
\hline Walton & & 1 & & 1 \\
\hline $\begin{array}{l}\text { Out of state or county } \\
\text { not available }\end{array}$ & 8 & 3 & 3 & 14 \\
\hline Grand Total & 434 & 191 & 213 & 838 \\
\hline
\end{tabular}


Table 2. Disposition of telephone survey calls.

\begin{tabular}{lrrrr}
\multicolumn{1}{c}{ Call Discposition } & $\begin{array}{c}\text { Total All } \\
\text { Groups }\end{array}$ & $\begin{array}{c}\text { Wholesale } \\
\text { Nurseries }\end{array}$ & Landscapers & Retailers \\
\hline & 587 & Number of calls & \\
Complete & 257 & 126 & 204 \\
Partial Complete & 3 & & & 3 \\
Strong Refusal & 77 & 23 & 25 & 29 \\
Soft Refusal & 737 & 186 & 190 & 361 \\
Answer Machine, Message & 373 & 112 & 194 & 67 \\
Language Unable & 72 & 52 & 5 & 15 \\
Busy & 128 & 35 & 40 & 53 \\
No Answer & 600 & 175 & 232 & 193 \\
Technical Phone Problems & 4 & 1 & 1 & 2 \\
Cell Phone & 16 & 4 & 4 & 8 \\
Callback, Respondent Not Selected & 272 & 61 & 87 & 124 \\
Callback, Respondent Selected & 91 & 15 & 13 & 63 \\
\hline Total Qualified & 2,960 & 921 & 917 & 1,122 \\
\hline Respondent Never Available* & 29 & 6 & 17 & 6 \\
Phys/Mentally Unable* & 3 & 2 & 1 & \\
Misc Unable* & 9 & 3 & 4 & 2 \\
Non-working Number* & 845 & 166 & 405 & 274 \\
Disconnected Number* & 687 & 111 & 425 & 151 \\
Number Changed* & 33 & 8 & 16 & 9 \\
Business/Government/Other Org* & 10 & 3 & 3 & 4 \\
No Eligible Respondent* & 1,124 & 234 & 452 & 438 \\
Answer Machine, No Message* & 1,061 & 289 & 504 & 268 \\
Fax/Data Line* & 154 & 28 & 97 & 29 \\
Institution* & 2 & 1 & & 1 \\
\hline Total Disqualified & 3,957 & 851 & 1,924 & 1,182 \\
\hline Total Attempted & 6,917 & 1,772 & 2,841 & 2,304 \\
\hline Percent Qualified & $42.8 \%$ & $52.0 \%$ & $32.3 \%$ & $48.7 \%$ \\
\hline$*$ Disquafy & & & & \\
\hline
\end{tabular}

* Disqualifying reason

\section{Survey Data and Economic Impact Analysis}

Analysis of the survey data was carried out with spreadsheet software (Microsoft Excel). Descriptive statistics were computed for each survey variable, including the mean (average), standard error, number of respondents, and sum of sample values. The value of sales for each firm was estimated at the midpoint value of the range selected (Table 10), unless a specific value was reported. Sales of specific products or services by industry firms, and sales by market segment or region, were estimated as a percentage of total sales for each industry sector. The total value of sales and employment in each industry sector were estimated based on the following formula: $\mathrm{O}_{\mathrm{i}}=\mathrm{M}_{\mathrm{i}} / \mathrm{S}_{\mathrm{i}} * \mathrm{P}_{\mathrm{i}} * \mathrm{Q}_{\mathrm{i}}$, where $\mathrm{O}_{\mathrm{i}}$ is estimated sales or employment in sector $\mathrm{i}$ (nursery, landscape, or retail), $M_{i}$ is the survey sample sales or employment reported, $S_{i}$ is the number of firms that reported sales or employment, $P_{i}$ is the population of firms, and $Q_{i}$ is the percentage of firms qualified for the telephone survey according to the disposition of calls (Table 2). Survey sample numbers and expansion factors for each industry sector are shown in Table 3. Expansion factors for the nursery sector were computed separately by firm size class, based upon the Florida Division of Plant Industry inventory numbers: small (1,000 to 5,000 plant units), medium (5,001 to 50,000 units), large (50,001 to 500,000 units), and very large (over 500,000 units). Sales expansion factors were 5.5 for nurseries, 18.6 for landscape firms, and 30.6 for retail firms, while employment expansion factors were 4.6, 14.9 and 18.6, respectively. 
Table 3. Survey sample size and expansion factors.

\begin{tabular}{|c|c|c|c|c|c|c|c|c|c|}
\hline \multirow{2}{*}{$\begin{array}{l}\text { Industry } \\
\text { Sector }\end{array}$} & \multirow{2}{*}{$\begin{array}{c}\text { Population } \\
\text { of Firms in } \\
\text { Florida }\end{array}$} & \multicolumn{3}{|c|}{$\begin{array}{c}\text { Number Firms } \\
\text { Surveyed }\end{array}$} & \multirow{2}{*}{$\begin{array}{l}\text { Percent of } \\
\text { Firms } \\
\text { Qualified } \\
\text { (telelphone } \\
\text { survey) }\end{array}$} & \multirow{2}{*}{$\begin{array}{c}\text { Firms } \\
\text { Reporting } \\
\text { Sales }\end{array}$} & \multirow{2}{*}{$\begin{array}{l}\text { Sales } \\
\text { Expan- } \\
\text { sion } \\
\text { Factor }\end{array}$} & \multirow{2}{*}{$\begin{array}{c}\text { Firms } \\
\text { Reporting } \\
\text { Employ- } \\
\text { ment }\end{array}$} & \multirow{2}{*}{$\begin{array}{l}\text { Employ- } \\
\text { ment } \\
\text { Expan- } \\
\text { sion } \\
\text { Factor } \\
\end{array}$} \\
\hline & & $\begin{array}{l}\text { Inter- } \\
\text { net }\end{array}$ & $\begin{array}{l}\text { Tele- } \\
\text { phone }\end{array}$ & Total & & & & & \\
\hline Nurseries & 4,477 & 176 & 258 & 434 & $52.0 \%$ & $78.6 \%$ & 5.5 & $94.7 \%$ & 4.6 \\
\hline Landscape & 8,467 & 65 & 126 & 191 & $32.3 \%$ & $77.0 \%$ & 18.6 & $96.3 \%$ & 14.9 \\
\hline Retailers & 7,359 & 9 & 204 & 213 & $48.7 \%$ & $54.9 \%$ & 30.6 & $90.6 \%$ & 18.6 \\
\hline Total & 20,303 & 250 & 588 & 838 & $42.8 \%$ & $72.2 \%$ & & $94.0 \%$ & \\
\hline
\end{tabular}

Economic impacts were estimated using a regional input-out model and social accounting matrix developed using the IMPLAN Pro software and the associated databases for Florida (2003) licensed from MIG, Inc. ${ }^{6}$ The IMPLAN databases consist of a set of socioeconomic accounts which describe the structure of the US economy in terms of transactions between households, governments, and 509 industry sectors classified on the basis of the primary commodity or service produced, according to the North American Industry Classification System (NAICS). The databases also describe local or regional economies in terms of industry output, value added, employment, imports and exports. A variety of statistical sources are used to construct these databases, including the annual and 5-year economic censuses conducted by the US Commerce Department and US Bureau of Labor Statistics. IMPLAN uses a matrix inversion procedure to develop economic multipliers which reflect the direct, indirect and induced impacts of specified changes in output or employment for any given industrial sector. Indirect impacts result from changes in economic activity of other industrial sectors which supply goods or services to the sector being evaluated. Induced impacts are the result of personal consumption expenditures by industry employees. The total economic impact is the sum of direct, indirect and induced impacts.

An IMPLAN model for Florida was constructed with all social accounts included, and all parameters set at default values. Economic multipliers for output (revenue), employment, value added, labor income, and indirect business taxes were compiled for each sector of the horticulture industry in Florida (Table 4).

Table 4. Economic multipliers for the environmental horticultural industry sectors in Florida.

\begin{tabular}{|c|c|c|c|c|}
\hline \multicolumn{2}{|c|}{ Multiplier/Effect } & \multirow[t]{2}{*}{ 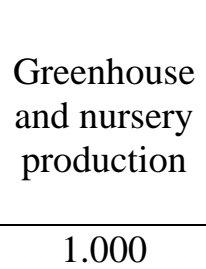 } & \multirow[t]{2}{*}{$\begin{array}{c}\text { Services to } \\
\text { buildings and } \\
\text { dwellings } \\
\text { (Landscape) }\end{array}$} & \multirow[t]{2}{*}{$\begin{array}{c}\text { Building } \\
\text { material and } \\
\text { garden } \\
\text { supply stores } \\
\text { (Retailers) }\end{array}$} \\
\hline & Direct & & & \\
\hline oross maroin on sales) & Indirect & 0.027 & 0.413 & 0.212 \\
\hline & Induced & 1.358 & 1.193 & 1.405 \\
\hline \multirow{3}{*}{$\begin{array}{l}\text { Employment (jobs per } \\
\text { million dollars output) }\end{array}$} & Direct & 11.9 & 19.2 & 14.9 \\
\hline & Indirect & 0.4 & 4.6 & 1.9 \\
\hline & Induced & 14.6 & 13.0 & 15.7 \\
\hline \multirow{3}{*}{$\begin{array}{l}\text { Value Added (personal } \\
\text { and business net income) }\end{array}$} & Direct & 0.959 & 0.515 & 0.778 \\
\hline & Indirect & 0.018 & 0.260 & 0.127 \\
\hline & Induced & 0.842 & 0.750 & 0.898 \\
\hline \multirow{3}{*}{$\begin{array}{l}\text { Labor Income (employee } \\
\text { salaries and wages, } \\
\text { business owner profits) }\end{array}$} & Direct & 0.377 & 0.410 & 0.463 \\
\hline & Indirect & 0.011 & 0.162 & 0.078 \\
\hline & Induced & 0.551 & 0.481 & 0.593 \\
\hline \multirow{3}{*}{ Indirect Business Taxes } & Direct & 0.014 & 0.018 & 0.145 \\
\hline & Indirect & 0.001 & 0.023 & 0.009 \\
\hline & Induced & 0.065 & 0.060 & 0.067 \\
\hline
\end{tabular}

Source: Implan state data for Florida, 2003 (MIG, Inc., Stillwater, MN, Jan. 2006).

\footnotetext{
${ }^{6}$ Implan Professional Social Accounting and Impact Analysis Software, User's Guide, Analysis Guide and Data Guide, 2nd ed., 1997, MIG, Inc., Stillwater, MN, 378 p. (http://www.implan.com).
} 
The multipliers capture overall effects of economic activity in the horticulture industry, including activity in the supply chain by vendors selling inputs to the industry (indirect effects), and the spending by industry employees (induced effects). The magnitude of the multipliers represents the strength of linkages in the regional economy to other sectors and institutions, and the share of total inputs provided to industry firms by other businesses within the region. Economic impacts of each sector of the horticultural industry were calculated using the direct effects multiplier on local or in-state sales, and the indirect and induced effects multipliers on non-local or out-of-state sales according to the following formula:

$$
I_{i j}=S_{i} \times G_{i} \times\left[A_{i j}+E_{i} \times\left(B_{i j}+C_{i j}\right)\right] \text {; }
$$

where $\mathrm{I}_{\mathrm{ij}}$ is total impact for measures (j) of output, employment, value added, labor income, or indirect business taxes, in each sector ( $\mathrm{i}$ = nursery, landscape or retail),

$\mathrm{S}_{\mathrm{i}}$ is industry sales in sector $\mathrm{i}$,

$E_{i}$ is the proportion of industry sales exported or shipped outside Florida by sector $i$,

$A_{i j}$ is the direct effects multiplier for measure $j$ in sector $i$,

$B_{i j}$ is the indirect effects multiplier for measure $j$ in sector $i$,

$\mathrm{C}_{\mathrm{ij}}$ is the induced effects multiplier for measure $\mathrm{j}$ in sector $\mathrm{i}$,

$\mathrm{G}_{\mathrm{i}}$ is the gross margin on sales for retailers (retail sector only).

Non-local (export) sales were treated differently because they bring "new" money into the local economy to expand economic activity ${ }^{7}$. Total employment impacts were estimated from survey data for the direct effects, and from multipliers for the indirect and induced effects. Output of the retail sector was taken as the gross margin on sales estimated using the Annual Benchmark Report for Retail Trade (US Commerce Dept., 2005).

County and regional economic impacts were estimated from totals for the state of Florida, based on the share of statewide direct employment reported to the Florida Department of Labor for the first three quarters of 2005 (Table 5). The sector "Services to buildings" included landscaping services, while the sectors "Lawn and garden stores, "building material and supplies stores”, and "florists” represented horticultural retailers. In some cases where employment was not reported for small counties due to nondisclosure rules, these amounts were estimated at the statewide average employment per firm.

Table 5. Reported employment and wages in environmental horticulture, by Florida County, Jan-Sep., 2005.

\begin{tabular}{|c|c|c|c|c|c|c|c|c|}
\hline \multirow[b]{2}{*}{ County } & \multirow[b]{2}{*}{$\begin{array}{l}\text { Number } \\
\text { Firms } \\
\text { Reporting }\end{array}$} & \multicolumn{6}{|c|}{ Employment (jobs) } & \multirow[b]{2}{*}{$\begin{array}{c}\text { Total } \\
\text { Wages Paid } \\
(\$ 1000)\end{array}$} \\
\hline & & $\begin{array}{l}\text { Green- } \\
\text { house and } \\
\text { nursery } \\
\text { production }\end{array}$ & $\begin{array}{l}\text { Services to } \\
\text { buildings } \\
\text { (incl. } \\
\text { landscape } \\
\text { services) }\end{array}$ & $\begin{array}{l}\text { Lawn } \\
\text { and } \\
\text { garden } \\
\text { stores }\end{array}$ & $\begin{array}{l}\text { Building } \\
\text { material } \\
\text { and } \\
\text { supplies } \\
\text { stores } \\
\end{array}$ & Florists & $\begin{array}{c}\text { All } \\
\text { Selected } \\
\text { Sectors }\end{array}$ & \\
\hline Alachua & 271 & 216 & 1,301 & 192 & 773 & 93 & 2,575 & 44,681 \\
\hline Baker & 29 & na & 45 & 16 & 28 & na & 89 & 920 \\
\hline Bay & 217 & na & 1,138 & 50 & 837 & 57 & 2,082 & 34,858 \\
\hline Bradford & 25 & na & 36 & na & 50 & na & 86 & 1,738 \\
\hline Brevard & 689 & 76 & 2,671 & 190 & 2,633 & 157 & 5,727 & 104,082 \\
\hline Broward & 2,358 & 467 & 12,172 & 326 & 6,861 & 464 & 20,291 & 357,142 \\
\hline Calhoun & 11 & na & 12 & na & 39 & na & 51 & 930 \\
\hline Charlotte & 224 & 52 & 657 & 61 & 765 & 56 & 1,592 & 29,038 \\
\hline Citrus & 172 & 29 & 618 & 27 & 578 & 31 & 1,282 & 21,388 \\
\hline Clay & 199 & na & 664 & 99 & 850 & 43 & 1,656 & 26,105 \\
\hline Collier & 785 & 459 & 3,826 & 200 & 2,152 & 155 & 6,792 & 147,052 \\
\hline Columbia & 44 & na & 170 & 35 & 228 & 14 & 447 & 7,923 \\
\hline Desoto & 38 & 154 & 62 & 42 & 39 & na & 297 & 6,907 \\
\hline Dixie & 8 & na & na & na & 46 & na & 46 & 311 \\
\hline Duval & 1,161 & 247 & 7,785 & 219 & 4,161 & 269 & 12,682 & 231,921 \\
\hline Escambia & 319 & na & 1,510 & 193 & 1,543 & 108 & 3,354 & 61,355 \\
\hline Flagler & 150 & 192 & 660 & 38 & 423 & 30 & 1,343 & 24,807 \\
\hline Franklin & 16 & na & 9 & na & 79 & 8 & 96 & 1,756 \\
\hline Gadsden & 44 & 1,304 & 276 & na & 57 & na & 1,637 & 33,579 \\
\hline Gilchrist & 18 & na & 28 & na & 41 & na & 70 & 1,096 \\
\hline
\end{tabular}

\footnotetext{
${ }^{7}$ Mulkey, W.David and AlanW. Hodges. Using Implan to Assess Local Economic Impacts. UF/IFAS Extension Fact Sheet, 10 pages, 2000. Available at http://edis.ifas.ufl.edu/FE168.
} 


\begin{tabular}{|c|c|c|c|c|c|c|c|c|}
\hline \multirow[b]{2}{*}{ County } & \multirow[b]{2}{*}{$\begin{array}{l}\text { Number } \\
\text { Firms } \\
\text { Reporting }\end{array}$} & \multicolumn{6}{|c|}{ Employment (jobs) } & \multirow[b]{2}{*}{$\begin{array}{c}\text { Total } \\
\text { Wages Paid } \\
(\$ 1000)\end{array}$} \\
\hline & & $\begin{array}{c}\text { Green- } \\
\text { house and } \\
\text { nursery } \\
\text { production }\end{array}$ & $\begin{array}{l}\text { Services to } \\
\text { buildings } \\
\text { (incl. } \\
\text { landscape } \\
\text { services) }\end{array}$ & $\begin{array}{l}\text { Lawn } \\
\text { and } \\
\text { garden } \\
\text { stores }\end{array}$ & $\begin{array}{l}\text { Building } \\
\text { material } \\
\text { and } \\
\text { supplies } \\
\text { stores } \\
\end{array}$ & Florists & $\begin{array}{c}\text { All } \\
\text { Selected } \\
\text { Sectors }\end{array}$ & \\
\hline Glades & 9 & na & 22 & na & na & na & 22 & 373 \\
\hline Gulf & 14 & na & 29 & na & 34 & na & 64 & 1,483 \\
\hline Hamilton & 9 & na & na & na & na & na & na & na \\
\hline Hardee & 37 & 213 & 62 & 37 & na & na & 313 & 5,881 \\
\hline Hendry & 44 & na & 147 & 19 & 137 & 14 & 317 & 4,421 \\
\hline Hernando & 206 & 68 & 951 & 46 & 551 & 48 & 1,664 & 28,334 \\
\hline Highlands & 152 & 326 & 390 & 90 & 362 & 75 & 1,243 & 20,818 \\
\hline Hillsborough & 1,383 & 1,706 & 10,069 & 358 & 5,061 & 248 & 17,443 & 326,358 \\
\hline Holmes & 13 & na & 39 & na & 34 & na & 73 & 800 \\
\hline Indian River & 274 & na & 1,137 & 62 & 801 & 74 & 2,074 & 42,965 \\
\hline Jackson & 46 & 47 & 74 & 22 & 277 & 9 & 428 & 7,190 \\
\hline Jefferson & 24 & 146 & 26 & 37 & 26 & na & 234 & 3,851 \\
\hline Lafayette & 7 & na & na & 64 & na & na & 64 & 1,218 \\
\hline Lake & 428 & 1,194 & 1,827 & 218 & 2,077 & 116 & 5,433 & 106,890 \\
\hline Lee & 1,078 & 963 & 4,547 & 181 & 3,959 & 155 & 9,805 & 212,704 \\
\hline Leon & 306 & na & 2,142 & 226 & 1,119 & 76 & 3,562 & 56,061 \\
\hline Levy & 39 & 78 & 58 & 18 & 68 & 7 & 228 & 3,834 \\
\hline Liberty & 3 & na & na & na & na & na & na & na \\
\hline Madison & 18 & 61 & 12 & 24 & 66 & na & 163 & 2,308 \\
\hline Manatee & 488 & 577 & 2,176 & 77 & 1,206 & 83 & 4,118 & 76,332 \\
\hline Marion & 382 & 179 & 1,248 & 171 & 1,271 & 78 & 2,947 & 50,930 \\
\hline Martin & 333 & 445 & 1,642 & 30 & 1,108 & 62 & 3,286 & 64,361 \\
\hline Miami-Dade & 2,325 & 5,104 & 12,647 & 765 & 7,129 & 848 & 26,493 & 482,658 \\
\hline Monroe & 166 & na & 436 & 7 & 446 & 24 & 913 & 18,092 \\
\hline Nassau & 89 & na & 449 & 14 & 297 & 14 & 774 & 12,296 \\
\hline Okaloosa & 275 & na & 1,252 & 67 & 1,090 & 133 & 2,542 & 40,874 \\
\hline Okeechobee & 46 & 60 & 235 & 19 & 51 & na & 364 & 7,560 \\
\hline Orange & 1,469 & 2,899 & 12,030 & 254 & 4,610 & 308 & 20,101 & 387,907 \\
\hline Osceola & 306 & 224 & 1,706 & 69 & 840 & 38 & 2,876 & 49,388 \\
\hline Palm Beach & 2,262 & 1,684 & 12,993 & 411 & 5,191 & 337 & 20,616 & 378,839 \\
\hline Pasco & 502 & 178 & 2,412 & 112 & 1,406 & 84 & 4,191 & 77,614 \\
\hline Pinellas & 1,264 & 55 & 6,061 & 222 & 3,764 & 253 & 10,355 & 184,506 \\
\hline Polk & 619 & 510 & 2,826 & 241 & 2,659 & 147 & 6,383 & 117,836 \\
\hline Putnam & 92 & 268 & 210 & 18 & 363 & 39 & 899 & 13,708 \\
\hline St Johns & 213 & 138 & 864 & 165 & 583 & 29 & 1,779 & 35,381 \\
\hline St Lucie & 340 & 166 & 1,438 & 137 & 1,001 & 53 & 2,795 & 58,253 \\
\hline Santa Rosa & 166 & 72 & 712 & 33 & 746 & 47 & 1,610 & 25,764 \\
\hline Sarasota & 853 & 111 & 3,916 & 181 & 1,882 & 145 & 6,236 & 120,652 \\
\hline Seminole & 655 & 266 & 3,958 & 214 & 3,006 & 103 & 7,546 & 153,403 \\
\hline Sumter & 54 & 218 & 116 & 19 & 149 & 24 & 527 & 9,198 \\
\hline Suwannee & 50 & 40 & 123 & 51 & 136 & 13 & 363 & 5,912 \\
\hline Taylor & 23 & na & 60 & na & 64 & 14 & 138 & 1,762 \\
\hline Union & 10 & na & 36 & na & 12 & na & 48 & 375 \\
\hline Volusia & 801 & 2,061 & 2,441 & 151 & 2,349 & 149 & 7,151 & 126,733 \\
\hline Wakulla & 21 & na & 90 & na & 68 & na & 158 & 2,074 \\
\hline Walton & 91 & na & 458 & 43 & 182 & 33 & 715 & 13,288 \\
\hline Washington & 16 & 13 & 32 & na & na & na & 45 & 658 \\
\hline Total & 24,775 & 23,260 & 127,744 & 6,562 & 78,363 & 5,367 & 241,295 & 4,479,435 \\
\hline
\end{tabular}

Source: Florida Agency for Workforce Innovation, Labor Market Statistics, Quarterly Census of Employment and Wages Program (QCEW), Tallahassee, FL. "na” indicates data not available due to nondisclosure rules. 


\section{Survey Results}

\section{Longevity of Industry Firms}

Most firms surveyed were generally mature businesses, with about 40 to 45 percent of all firms having been in business for 20 years or more, and another 15 to 30 percent that had 11 to 19 years business experience (Figure 2). About 20 percent of nursery and retail firms had been in business for one to five years.

Figure 2. Years in business reported by survey respondents.

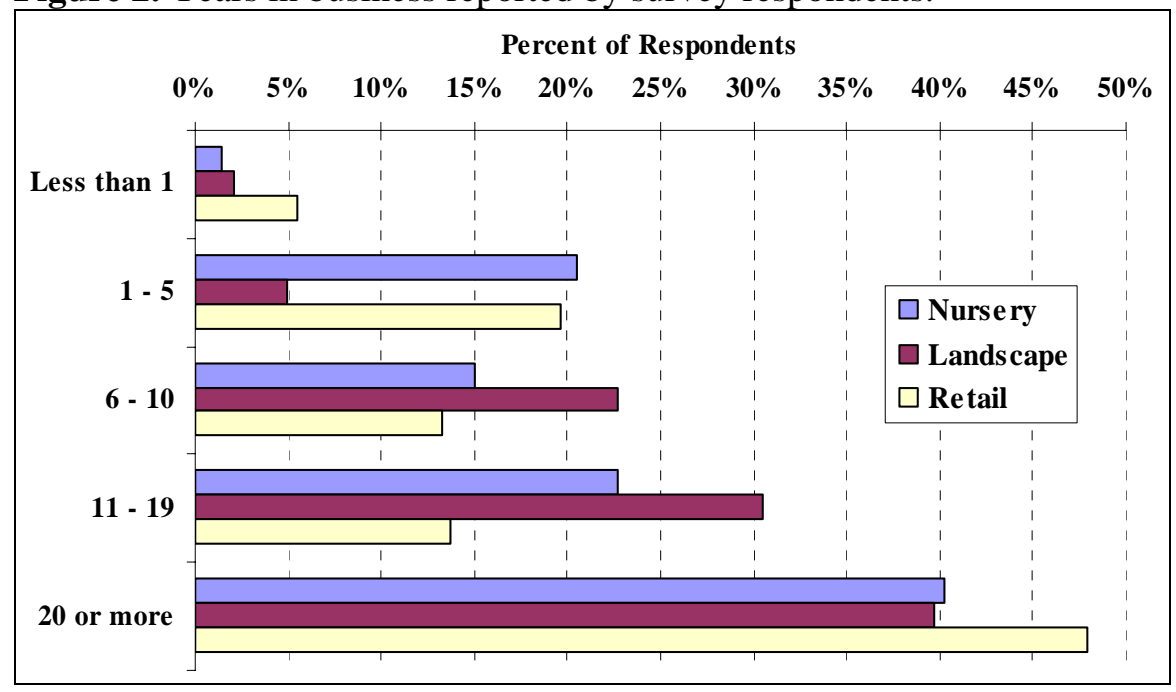

\section{Production Area Managed}

A majority of growers with greenhouses or shadehouse had small production areas (less than 10,000 sq.ft.), while a few had very large areas over 1 million square feet (Figure 3). For container or field production areas, 3 and 4 percent of respondents reported having more than 100 acres, while 36 percent and 31 percent of respondents reported having less than 5 acres of production area, respectively (Figure 4). Total production area reported by survey respondents was 82,440 acres, including 57,843 acres for container production, 23,608 acres for field production, and 989 acres (43.1 million square feet) for greenhouses or shadehouses (Table 6).

Figure 3. Greenhouse or shadehouse area reported by survey respondents.

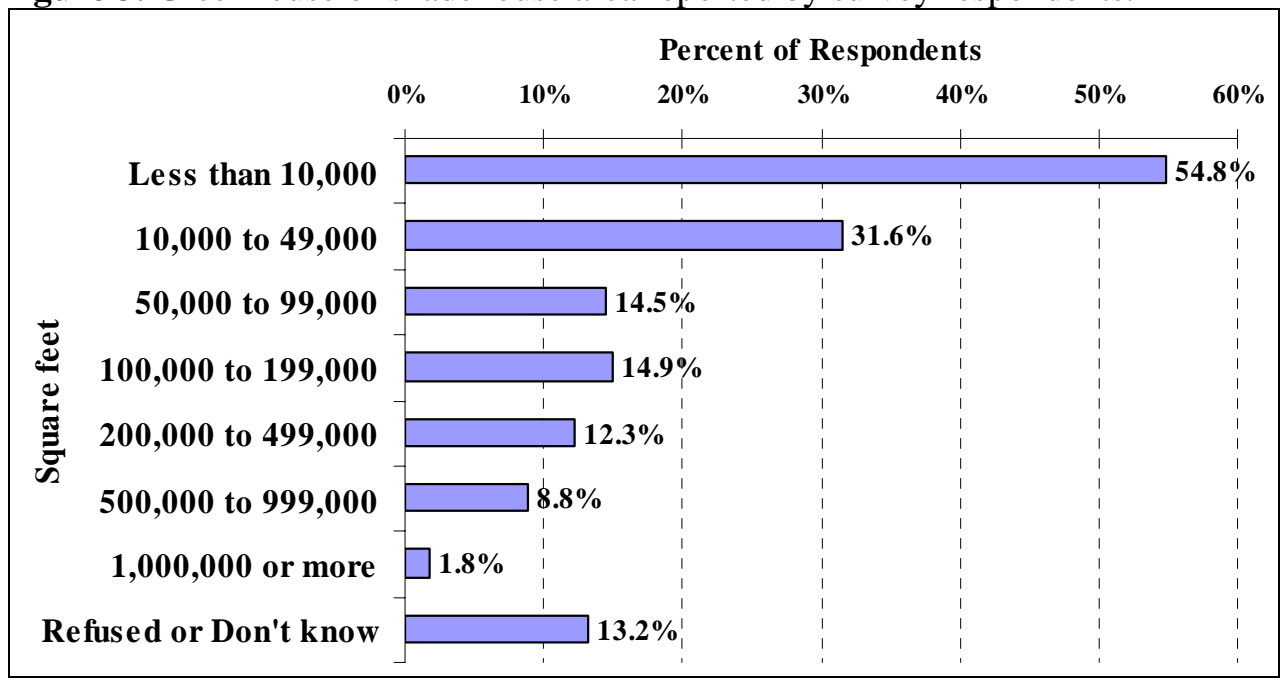


Figure 4. Container and field nursery area reported by survey respondents.

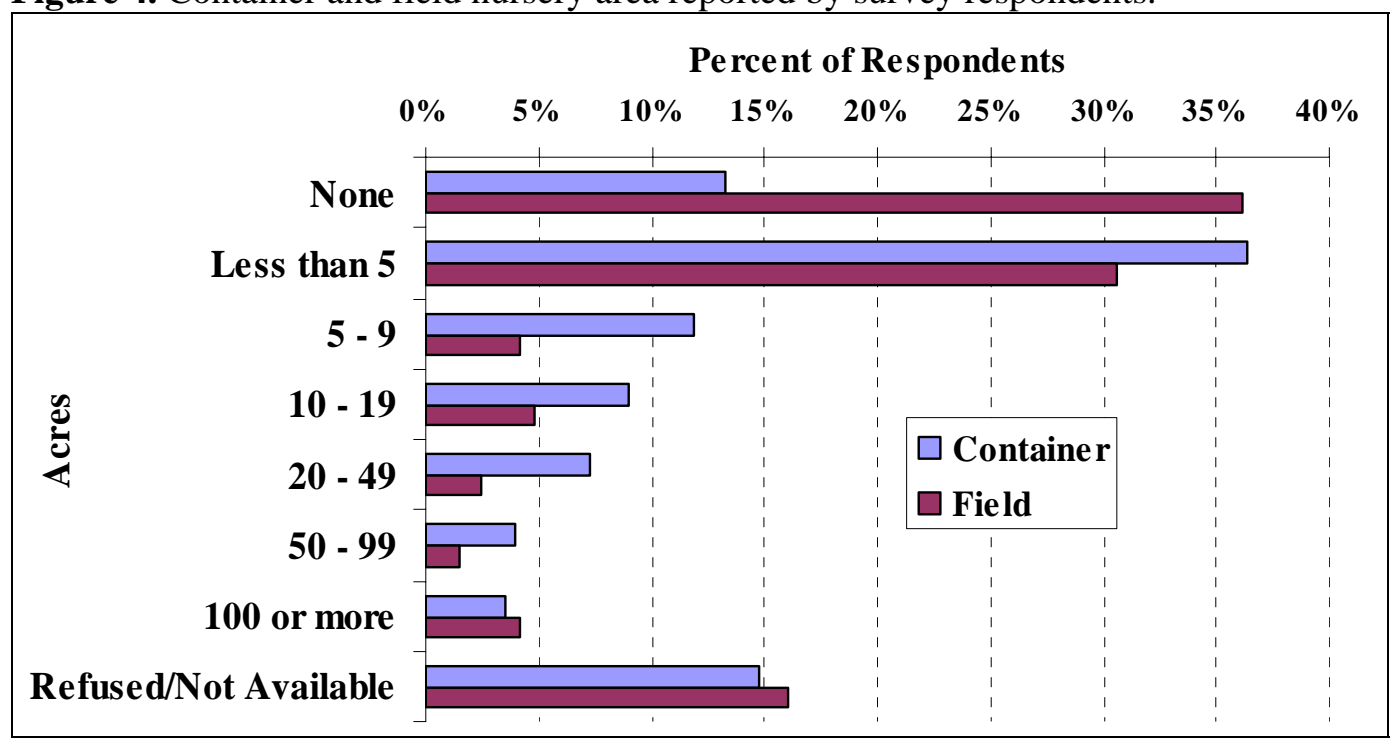

Table 6. Nursery production area reported.

\begin{tabular}{lr}
\multicolumn{1}{c}{ Type Growing Area } & \multicolumn{1}{c}{ Acres } \\
\hline Container & 57,843 \\
Field & 23,608 \\
Greenhouse/Shadehouse & 989 \\
\hline Total & 82,440 \\
\hline
\end{tabular}

\section{Employment}

Direct employment in 2005 reported by surveyed firms totaled 22,494 persons, including 7,811 employees in nurseries, 5,541 in landscape services, and 9,142 by horticultural retailers, with 15,900 (65\%) as full time employees, and 6,594 (35\%) as part-time, temporary or seasonal employees (Table 7). Part-time employment was reported by 81 percent of nurseries, 78 percent of landscape firms and 88 percent of retailers. The sample employment figures reported by survey respondents were used to estimate total employment in the industry according to the expansion factors discussed under methods. Total industry employment was estimated at 294,179 jobs, including 190,384 fulltime and 103,794 part-time, with 33,435 for nurseries, 87,914 for landscape services and 171,830 for retailers. These employment figures are significantly higher than the number of employees reported to the Florida Department of Labor for purposes of unemployment compensation because self-employed persons are not required to report employment and payroll to the government.

Table 7. Employment in the Florida environmental horticulture industry, 2005

\begin{tabular}{lrrr|rrr} 
& \multicolumn{3}{c|}{ Employment Reported by Survey } & \multicolumn{3}{c}{ Total Industry Employment } \\
\multicolumn{1}{c}{ Industry Sector } & \multicolumn{2}{c}{ Respondents (Jobs) } & \multicolumn{3}{c}{ (Jobs)* } \\
& Fulltime & Part-time & \multicolumn{1}{c}{ Total } & Fulltime & Part-time & \multicolumn{1}{c}{ Total } \\
\hline Nursery production & 6,230 & 1,581 & 7,811 & 25,659 & 8,776 & 33,435 \\
Landscape services & 4,004 & 1,537 & 5,541 & 59,513 & 28,402 & 87,914 \\
Horticultural retailing & 5,666 & 3,476 & 9,142 & 105,212 & 66,617 & 171,830 \\
\hline Total & 15,900 & 6,594 & 22,494 & 190,384 & 103,795 & 294,179 \\
\hline
\end{tabular}

* Estimated based on survey expansion factors (see methods). 


\section{Sales of Environmental Horticultural Products and Services}

Information on annual sales was reported by 79 percent of nurseries, 77 percent of landscape firms, and 55 percent of retailers surveyed. Respondents who reported annual sales of less than $\$ 500,000$ represented 42 percent of nurseries, 38 percent of landscape firms, and 32 percent of retailers surveyed, while those with annual sales exceeding \$10 million (Mn) were 1.6, 2.5 and 3.3 percent, respectively (Figure 5)

Total annual sales for each industry sector were estimated based on this number of respondents reporting annual sales in each class, and assuming sales equal to the midpoint value of the range, together with expansion factors, as discussed under methods. Sales reported by survey respondents were $\$ 1.05$ billion (Bn). Total industry sales were estimated at $\$ 15.24 \mathrm{Bn}$, including $\$ 3.01 \mathrm{Bn}$ by nurseries, $\$ 5.25 \mathrm{Bn}$ by landscape service firms, and $\$ 6.97 \mathrm{Bn}$ by horticultural retailers (Table 8 ). In the nursery sector, secondary data on sales of turfgrass and cut foliage (ferns) were included in these estimated sales.

Figure 5. Distribution of respondents by annual sales class

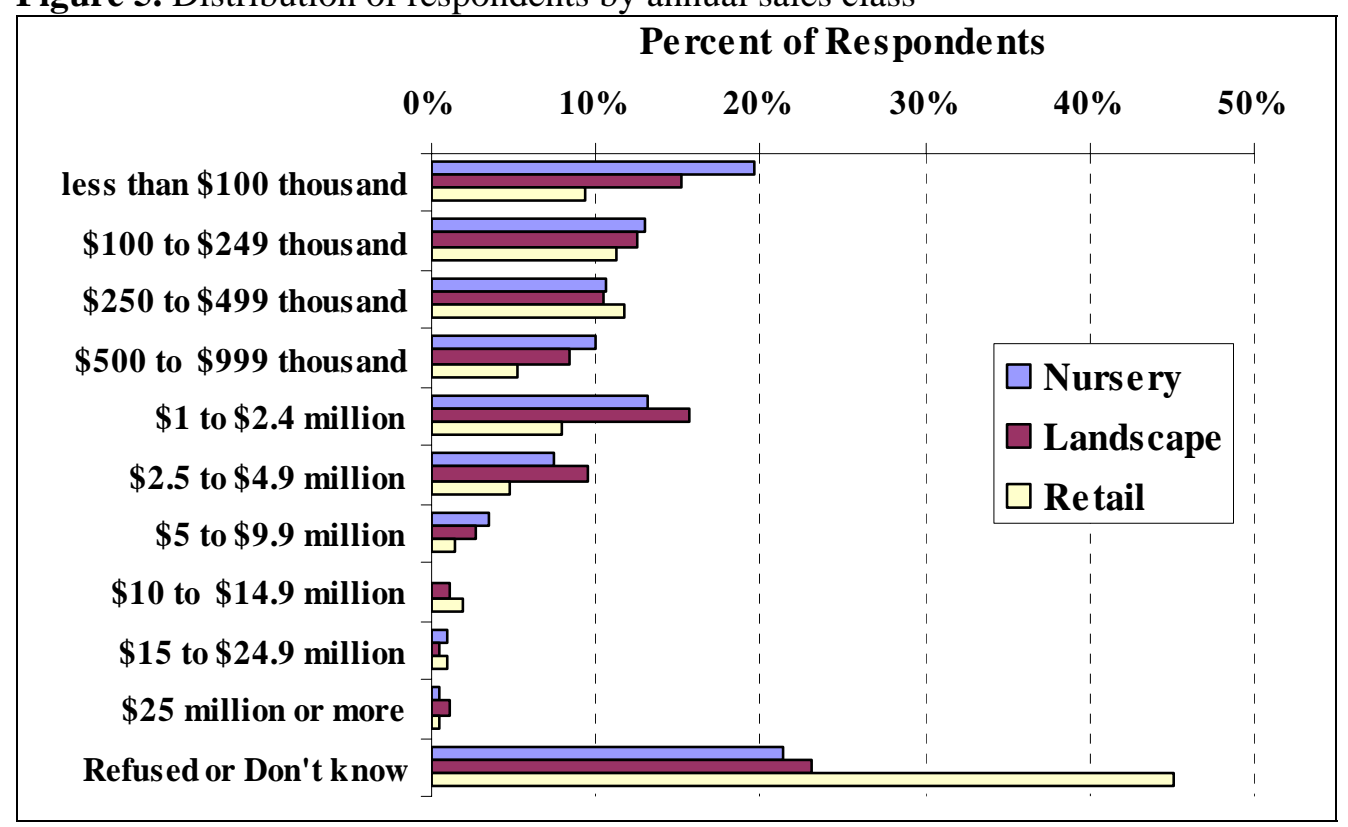

Table 8. Sales reported by survey respondents and estimated total industry sales, 2005.

\begin{tabular}{lrr} 
Industry Sector & $\begin{array}{c}\text { Total Sales } \\
\text { Reported } \\
\text { (Mn \$) }\end{array}$ & $\begin{array}{c}\text { Total } \\
\text { Industry } \\
\text { Sales } \\
(\mathrm{Mn} \mathrm{\$ )*}\end{array}$ \\
\hline Nursery production & 543.3 & $3,007.2$ \\
Landscape services & 282.7 & $5,254.8$ \\
Horticultural retailing & 227.6 & $6,970.6$ \\
\hline Total & $1,053.5$ & $15,236.5$ \\
\hline
\end{tabular}

* Estimated based on survey sample expansion factors (see methods).

Sales of industry firms were compiled by market region, including international, national, state, and local. The local area was defined as the city or county in which the business was located, or within a 50 mile radius. For nurseries, 32 percent of total sales were to local markets, 26 percent were to other areas within Florida, 14 percent were to other southeast U.S. states, 12 percent to northeast states, 8 percent to the midwest, 6 percent to western states, and 1 percent each to Canada and to other foreign countries (Figure 6). Thus, 42 percent of nursery sales were to markets outside the state and 58 percent were within Florida. For foliage growers specifically, 13 percent of total sales were to local markets, 12 percent were to other areas within Florida, 13 percent were to other southeast U.S. states, 30 percent to northeast states, 18 percent to the midwest, 9 percent to western states, 4 percent to Canada, and 1 percent to other foreign countries. For retailers and landscapers, most sales were to local or state markets, 99 percent and 88 percent, respectively. 
Figure 6. Distribution of nursery sales by market region.

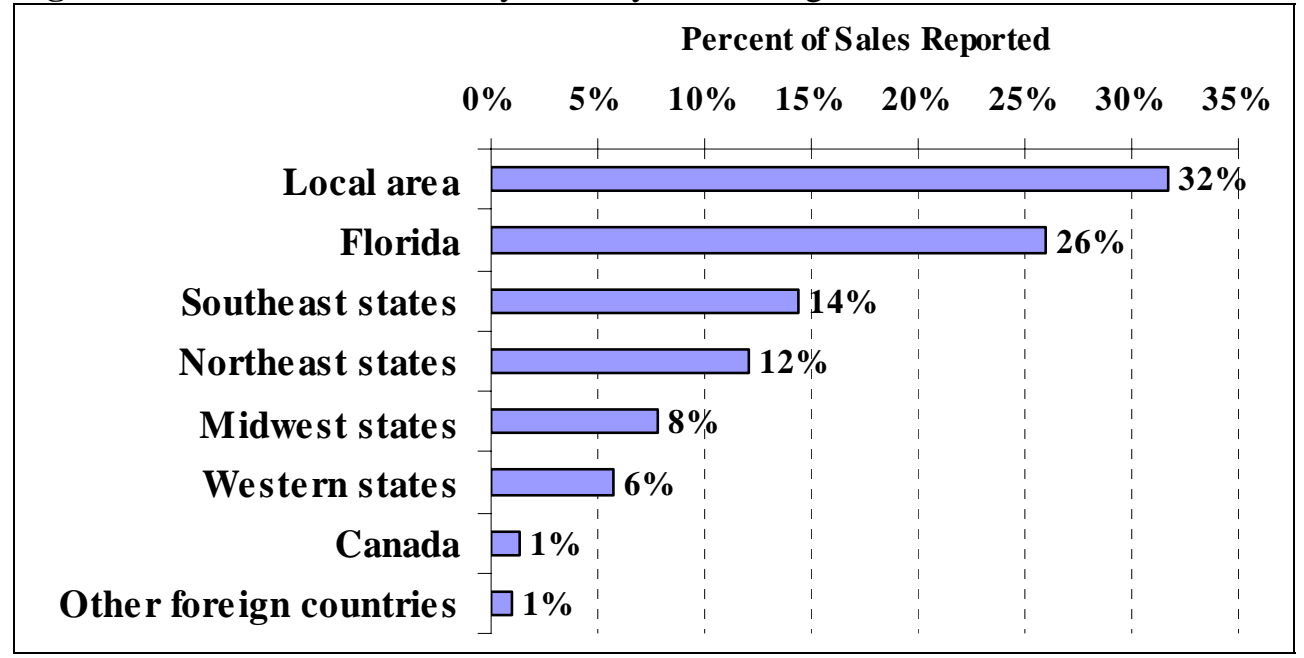

Sales of specific types of horticultural products and services are detailed in Figure 7 and Table 9. For nursery producers, the largest-selling product types were shrubs ( $\$ 578 \mathrm{Mn})$, representing 19 percent of total grower sales, followed by tropical foliage ( $\$ 437 \mathrm{Mn}, 15 \%)$, deciduous trees ( $\$ 389 \mathrm{Mn}, 13 \%)$, turfgrass (\$307 Mn, 10\%), liners (\$297 Mn, 10\%), and potted flowering plants (\$281 Mn, 9\%). Total sales of trees, including deciduous, evergreen and flowering trees amounted to $\$ 670 \mathrm{Mn}$ or 22 percent of grower sales. Palms were a major Florida specialty product, valued at $\$ 220 \mathrm{Mn}$, representing 7 percent of grower sales. Sales of miscellaneous other unspecified plant types amounted to 2 percent. Sales of turfgrass sod valued at $\$ 307 \mathrm{Mn}$

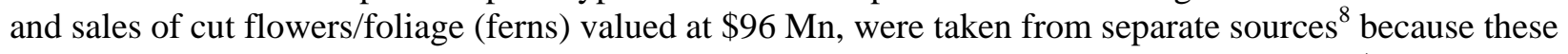
were not reported in this survey. Sales of plants native to the State of Florida were valued at \$316 Mn or 11 percent of total grower sales.

Figure 7. Plant product sales by growers.

\begin{tabular}{|c|c|c|c|c|c|c|}
\hline & \multicolumn{6}{|c|}{ million dollars } \\
\hline & 100 & 200 & 300 & 400 & & 600 \\
\hline Shrubs & - & & & & & 578 \\
\hline Tropical Foliage & ב & & & Z & & \\
\hline Deciduous Trees & & & & 389 & & \\
\hline Turfgrass & & & $\square 3$ & & & \\
\hline Liners & & & 729 & & & \\
\hline Potted Flowe ring Plants & - & & 281 & & & \\
\hline Palms & & & & & & \\
\hline Evergreen trees & - & & & & & \\
\hline Flowe ring trees & 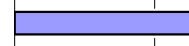 & & & & & \\
\hline Cut Foliage or Flowers & $\square 96$ & & & & & \\
\hline Ground Covers & $\square 66$ & & & & & \\
\hline Other Plants & $\square 54$ & & & & & \\
\hline
\end{tabular}

${ }^{8}$ Haydu, J.J., L.N. Satterthwaite and J.L Cisar. An economic and agronomic profile of Florida’s sod industry in 2003. Univ. Florida/IFAS Extension document, Apr. 2005, available at http://hortbusiness.ifas.ufl.edu.

Foliage, Floriculture and Cut Greens. Florida Agricultural Statistics Service, USDA, Orlando, May 2005. 
For the landscape services sector, landscape installation represented sales of $\$ 2.45 \mathrm{Bn}$, or 47 percent of total industry sales, while landscape maintenance represents $\$ 1.58 \mathrm{Bn}$ or 30 percent, landscape design was 10 percent and miscellaneous other landscape services were 14 percent.

Sales by horticultural retailers included plants valued at $\$ 2.75 \mathrm{Bn}$ or 40 percent of total sales, lawn and garden supplies such as fertilizers and chemicals valued at $\$ 2.14 \mathrm{Bn}(31 \%)$, horticultural hard goods such as tools and equipment values at $\$ 762 \mathrm{Mn}(11 \%)$, and miscellaneous other horticultural goods valued at \$1.31 Bn (19\%).

Table 9. Sales of specific types of environmental horticultural products and services

\begin{tabular}{|c|c|c|c|}
\hline Sector and Product/Service & $\begin{array}{c}\text { Value } \\
\text { Reported } \\
\text { (Mn \$) }\end{array}$ & $\begin{array}{c}\text { Expanded } \\
\text { Value } \\
\text { (Mn. \$) }\end{array}$ & $\begin{array}{l}\text { Percen } \\
\text { of Tota }\end{array}$ \\
\hline \multicolumn{4}{|l|}{ Nurseries } \\
\hline Shrubs & 115.7 & 578.7 & $19.2 \%$ \\
\hline Tropical foliage & 87.5 & 437.5 & $14.6 \%$ \\
\hline Deciduous trees & 77.7 & 388.9 & $12.9 \%$ \\
\hline Turfgrass* & na & 307.0 & $10.2 \%$ \\
\hline Liners & 59.4 & 297.0 & $9.9 \%$ \\
\hline Potted flowering plants & 56.1 & 280.9 & $9.3 \%$ \\
\hline Palms & 44.0 & 219.9 & $7.3 \%$ \\
\hline Evergreen trees & 29.4 & 147.2 & $4.9 \%$ \\
\hline Flowering trees & 26.6 & 133.3 & $4.4 \%$ \\
\hline Cut flowers/foliage (ferns)* & na & 96.2 & $3.2 \%$ \\
\hline Ground covers & 13.2 & 66.2 & $2.2 \%$ \\
\hline Other plants & 10.8 & 54.2 & $1.8 \%$ \\
\hline Total & 521.9 & $3,007.2$ & $100 \%$ \\
\hline Native plants & 55.0 & 316.9 & $10.5 \%$ \\
\hline \multicolumn{4}{|l|}{ Landscape Services } \\
\hline Landscape installation & 123.5 & $2,452.3$ & $46.6 \%$ \\
\hline Landscape maintenance & 79.7 & $1,582.9$ & $30.1 \%$ \\
\hline Landscape design & 25.6 & 509.2 & $9.7 \%$ \\
\hline Other landscape service & 36.0 & 714.0 & $13.6 \%$ \\
\hline Total & 264.8 & $5,258.5$ & $100 \%$ \\
\hline \multicolumn{4}{|l|}{ Retailers } \\
\hline Live plants & 52.9 & $2,752.5$ & $39.5 \%$ \\
\hline Lawn and garden supplies & 41.2 & $2,144.2$ & $30.8 \%$ \\
\hline Horticultural hard goods & 14.6 & 761.8 & $10.9 \%$ \\
\hline Other retail goods & 25.2 & $1,312.3$ & $18.8 \%$ \\
\hline Total & 134.0 & $6,970.9$ & $100 \%$ \\
\hline
\end{tabular}

* Values for turfgrass and cut flower/foliage were taken from secondary sources.

\section{Market Channels and Practices for Horticultural Products}

Sales of Florida horticultural products and services to different types of customers are summarized in Figures 8 through 10. For nurseries, the most important customers were other growers, representing 22 percent of total sales, re-wholesalers or brokers (21\%), and landscape contractors (19\%) (Figure 8). Also important were mass merchandise stores (9\%), independent retail garden centers (7\%), and interiorscapers (6\%). For landscape firms, the most important customer segments were governments (29\%), homeowners (24\%), builders and developers (23\%), commercial establishments (12\%) and apartments and condominiums (9\%) (Figure 9). For horticultural retailers the dominant market was homeowners, representing 63 percent of total sales, followed by apartments and condominiums (15\%), and commercial establishments (9\%) (Figure $10)$. 
Figure 8. Distribution of nursery product sales by type of customer.

\begin{tabular}{|c|c|c|c|c|c|}
\hline & \multicolumn{5}{|c|}{ Percent of Sales Reported } \\
\hline & $0 \%$ & $10 \%$ & $15 \%$ & $20 \%$ & $25 \%$ \\
\hline Other Growers & & & & ב & \\
\hline Rewholesalers & & & & $\square$ & \\
\hline Landscape Contractors & & & & $19 \%$ & \\
\hline Mass merchandise stores & E & $9 \%$ & & & \\
\hline Independent Retailers & ב & & & & \\
\hline Interiorscapers & +2 & & & & \\
\hline Landscape Maintenance & $\square$ 4\% & & & & \\
\hline Supermarkets & $4 \%$ & & & & \\
\hline Home Improvement Stores & $\square 2 \%$ & & & & \\
\hline Home owners & $2 \%$ & & & & \\
\hline Builders \& Developers & $\square 1 \%$ & & & & \\
\hline Other Type(s) Customer & $\square 1 \%$ & & & & \\
\hline
\end{tabular}

Figure 9. Distribution of landscape service sales by type of customer.

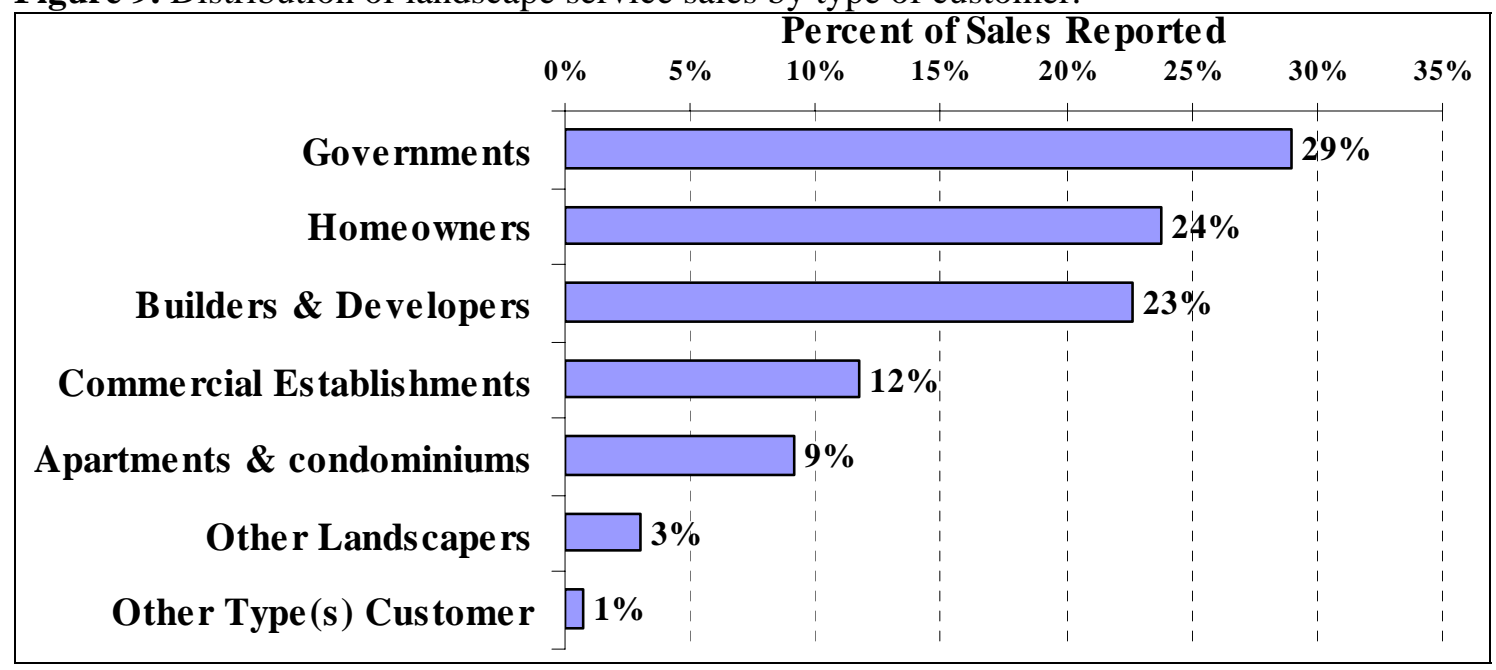

Figure 10. Distribution of retail horticultural product sales by type of customer.

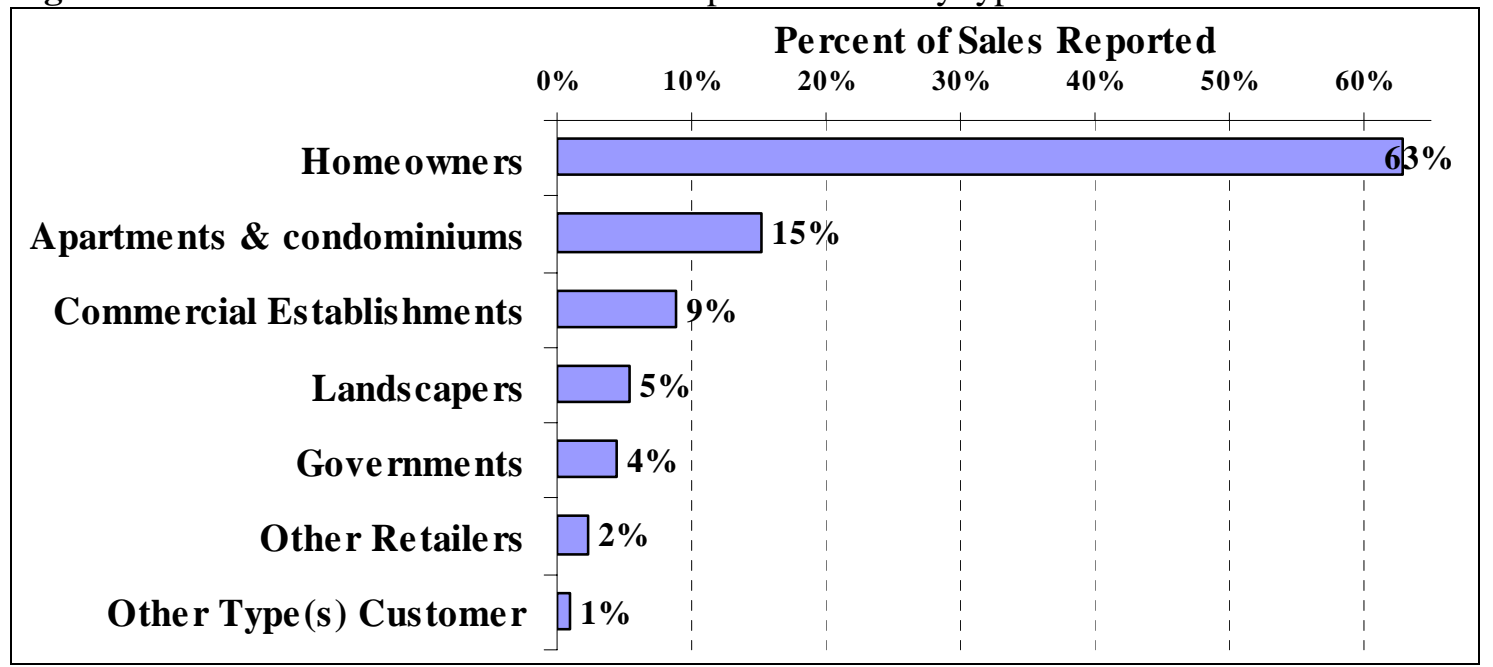


When nursery respondents were asked to indicate which type of market outlets are expanding, nearly 71 percent answered that “other growers” were a growing market, followed by rewholesalers (52\%), landscape contractors (47\%), interiorscapers (25\%), and landscape maintenance firms at 24 percent (Figure 11). It is apparent that the marketing of ornamental plants through brokers and other growers is becoming more developed in the industry, and that demand from landscape professionals is also strong, while demand from retailers is growing more slowly. For foliage growers specifically, a similar pattern was observed, with a somewhat higher percentage of respondents indicating that all of the top-ranked markets were expanding.

Figure 11. Markets for nursery products identified as expanding by survey respondents.

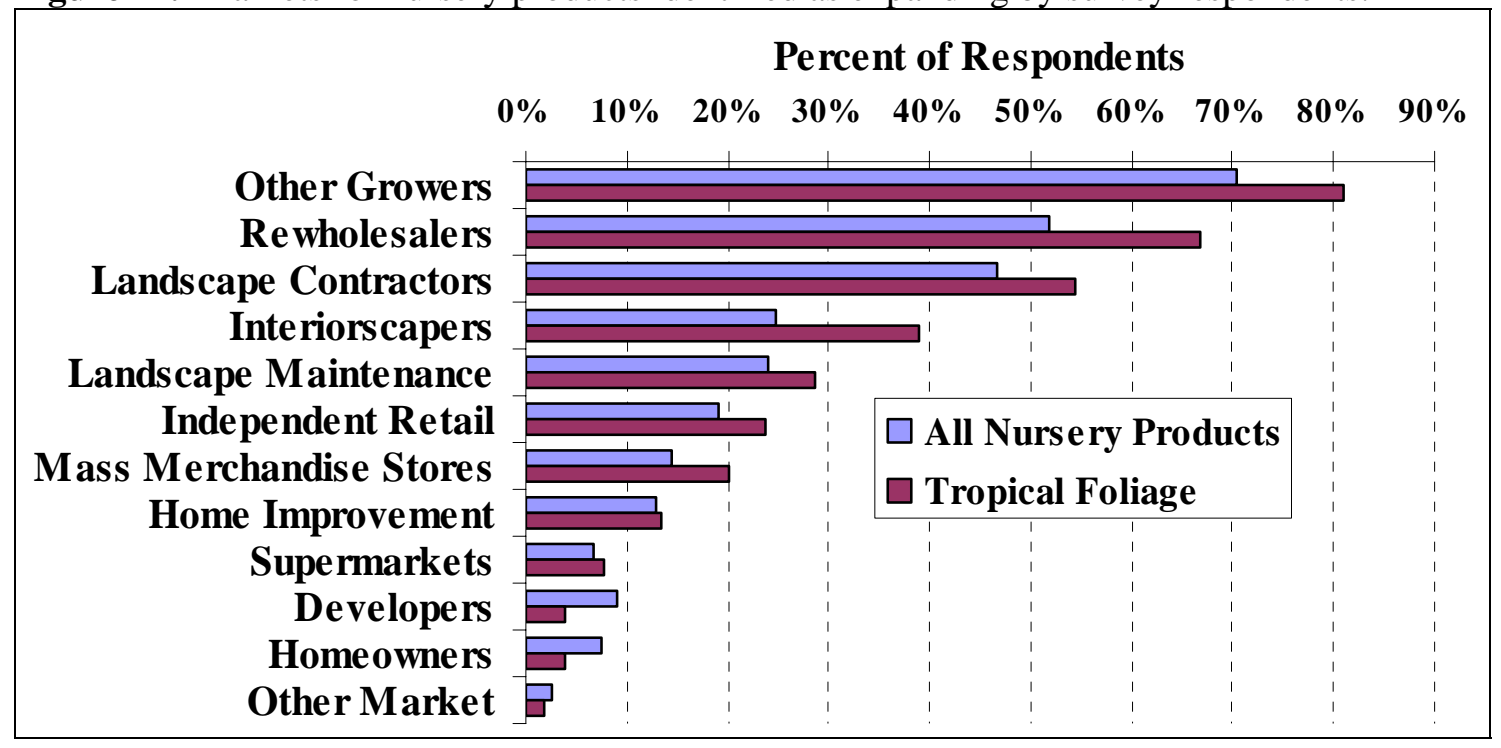

Marketing practices reported by survey respondents are summarized in Figure 12. The most commonly reported practices for nurseries were personal selling (57\%), trade shows (38\%), charitable contributions and civic events (37\%), and trade magazines (33\%). For landscapers, the most frequently cited practices were personal selling (49\%), civic event and charitable contributions (35\%), print media (31\%), and internet websites (26\%). Retailers reported generally higher use of most marketing practices, including charitable contributions and civic events (67\%), print media (54\%), internet websites (54\%), promotions (46\%) personal selling (43\%) and direct mail (41\%).

Figure 12. Marketing practices used by firms surveyed.

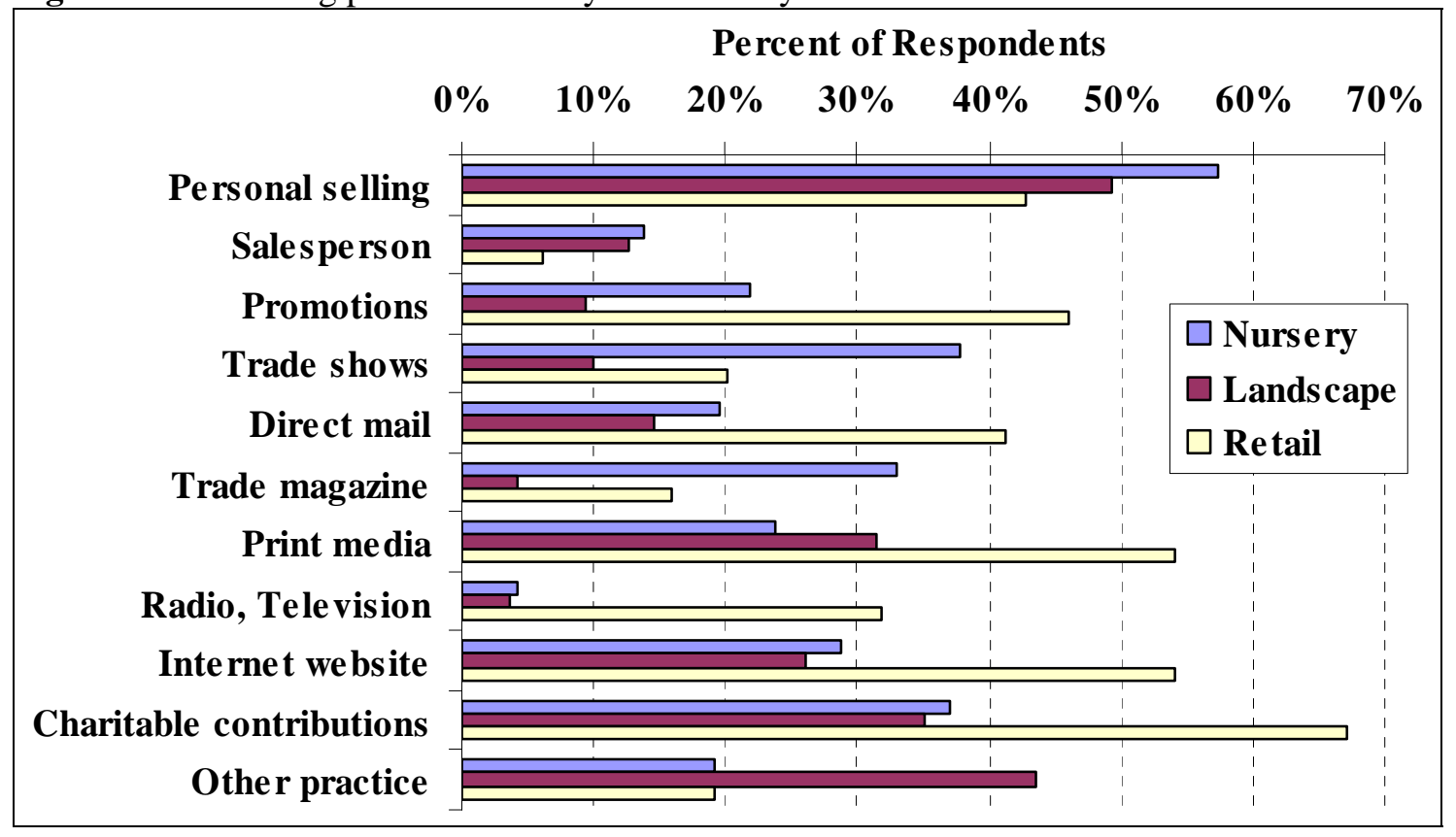




\section{Impacts of Hurricanes on the Environmental Horticulture Industry in 2004 and 2005}

The state of Florida was struck by an unprecedented series of eight major hurricanes during the 2004 and 2005 seasons. These storms did tremendous damage to infrastructure, and caused large losses of products for sale and to business activity throughout the state's economy, particularly the agricultural sector. Nearly 79 percent of survey firms in the environmental horticulture industry indicated that they were impacted by at least one of these hurricanes, including 83 percent of nurseries, 67 percent of landscape firms, and 82 percent of horticultural retailers. The largest percentages of all firms were affected by hurricanes Frances (53\%), Jeanne (44\%), Charley (43\%), and Wilma (42\%) (Figure 13).

Figure 13. Industry firms directly affected by named hurricanes in 2004 and 2005.

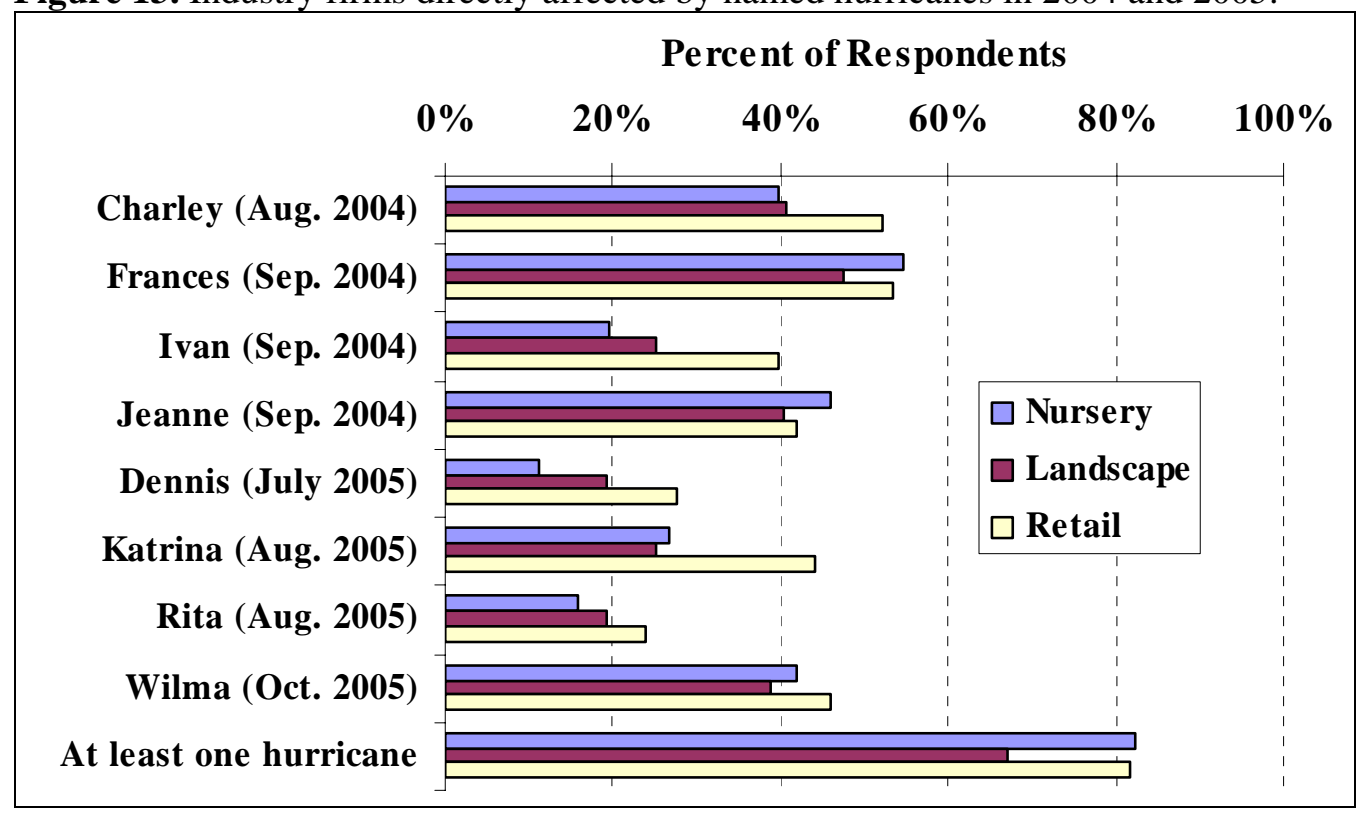

Survey respondents were asked to report losses of products (crops), structural damages, cleanup costs, and length of business interruption, either as a specific value or within a range of values offered. Losses of products for sale valued at $\$ 100,000$ or more were reported by 22 percent of all firms, while losses of at least $\$ 1$ million were reported by 4 percent of firms, including 7 percent of nurseries (Figure 14). Structural damages of at least $\$ 100,000$ were sustained by 12 percent of firms (Figure 15). Cleanup costs of at least $\$ 100,000$ were reported by 8 percent of firms (Figure 16). Nearly half (49\%) of firms had their business interrupted for 3 weeks or more (Figure 17).

This information reported by respondents was used to estimate total damages for the entire population of industry firms. Actual losses incurred were assumed to be at the midpoint of the range of values selected. Estimated total damages due to the hurricanes during 2004 and 2005 amounted to \$2.12 Bn including product losses of \$1.05 Bn, structural damages of \$465 Mn and cleanup costs of \$605 Mn (Table 10). Total losses were \$964 Mn for nurseries, \$675 Mn for landscape firms and \$482 Mn for retailers.

Table 10. Estimated total losses due to hurricanes in 2004 and 2005.

\begin{tabular}{lcccc}
\multicolumn{1}{c}{ Type Loss } & Nursery & Landscape & Retail & All Sectors \\
\hline & \multicolumn{4}{c}{ Million dollars } \\
Product (crop) Losses & 659.5 & 273.1 & 117.8 & $1,050.4$ \\
Structural Damage & 183.3 & 61.2 & 220.6 & 465.4 \\
Cleanup Costs & 121.5 & 340.5 & 143.3 & 605.3 \\
\hline Total & 964.3 & 674.8 & 481.8 & $2,120.9$ \\
\hline
\end{tabular}


Figure 14. Distribution of product (crop) losses due to hurricanes in 2004 and 2005.

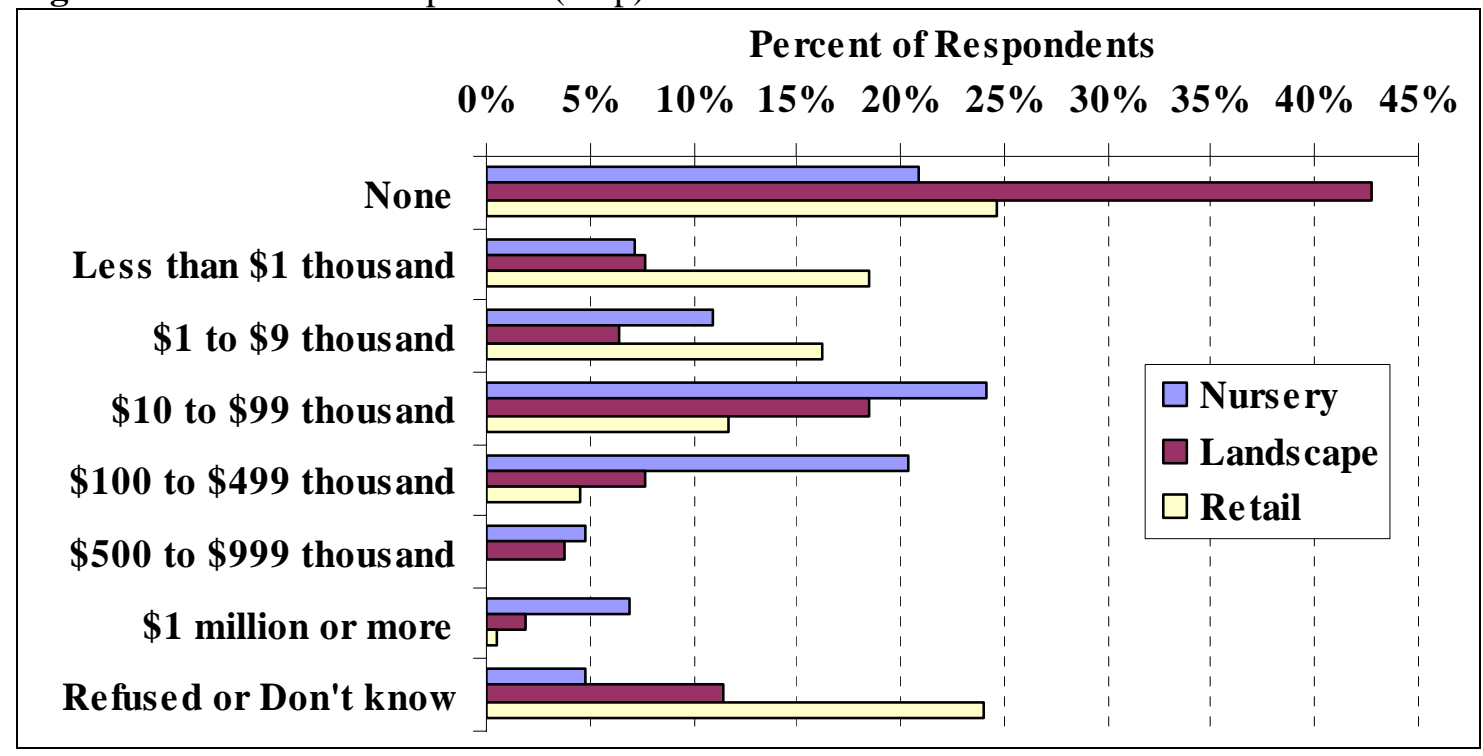

Figure 15. Distribution of structural damages due to hurricanes in 2004 and 2005.

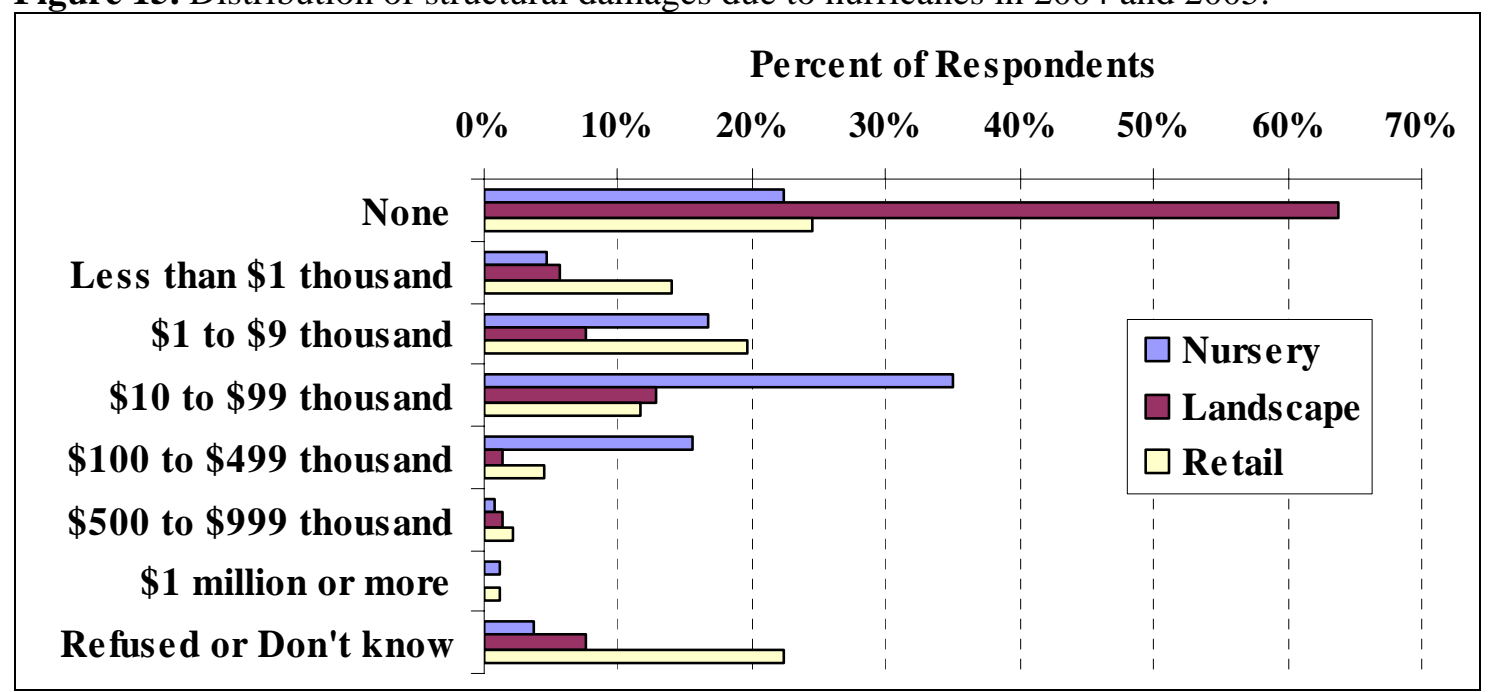

Figure 16. Distribution of cleanup costs due to hurricanes in 2004 and 2005.

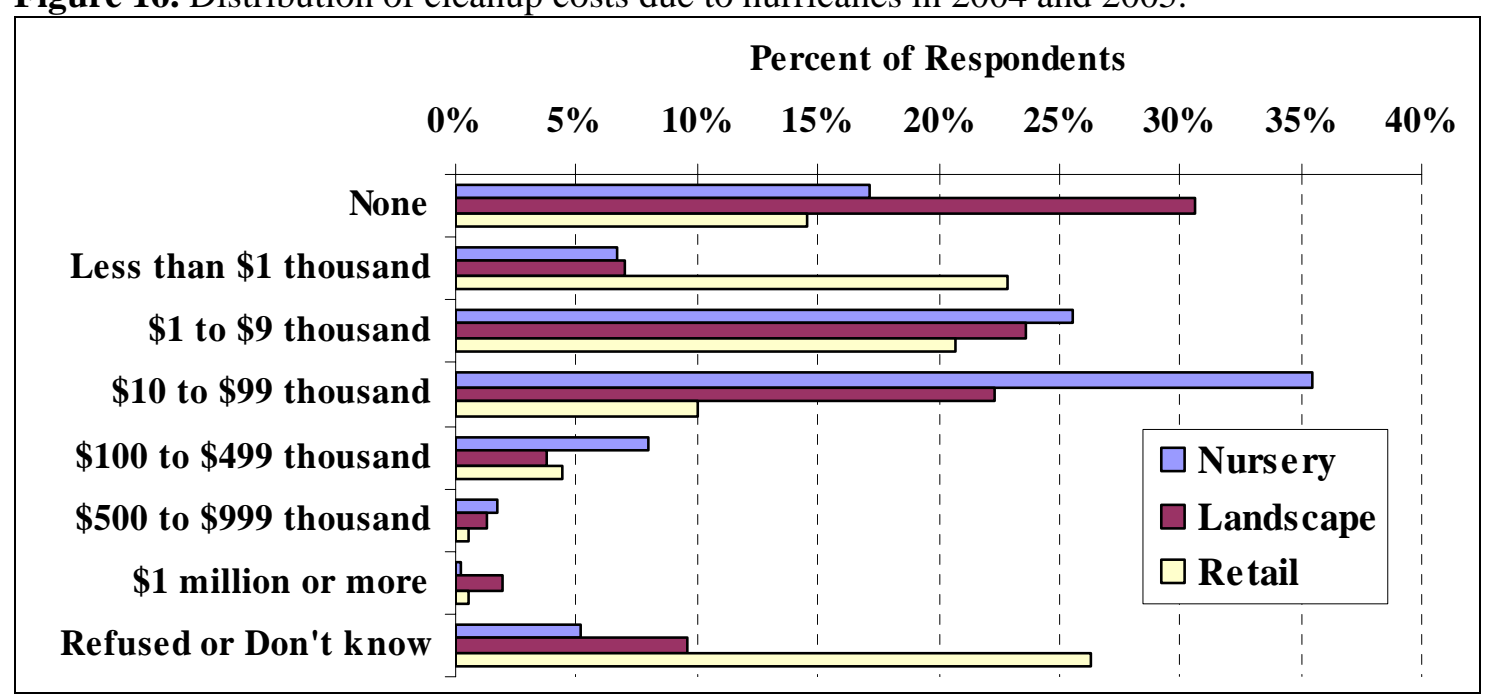


Figure 17. Distribution of total length of business interruption due to hurricanes in 2004 and 2005.

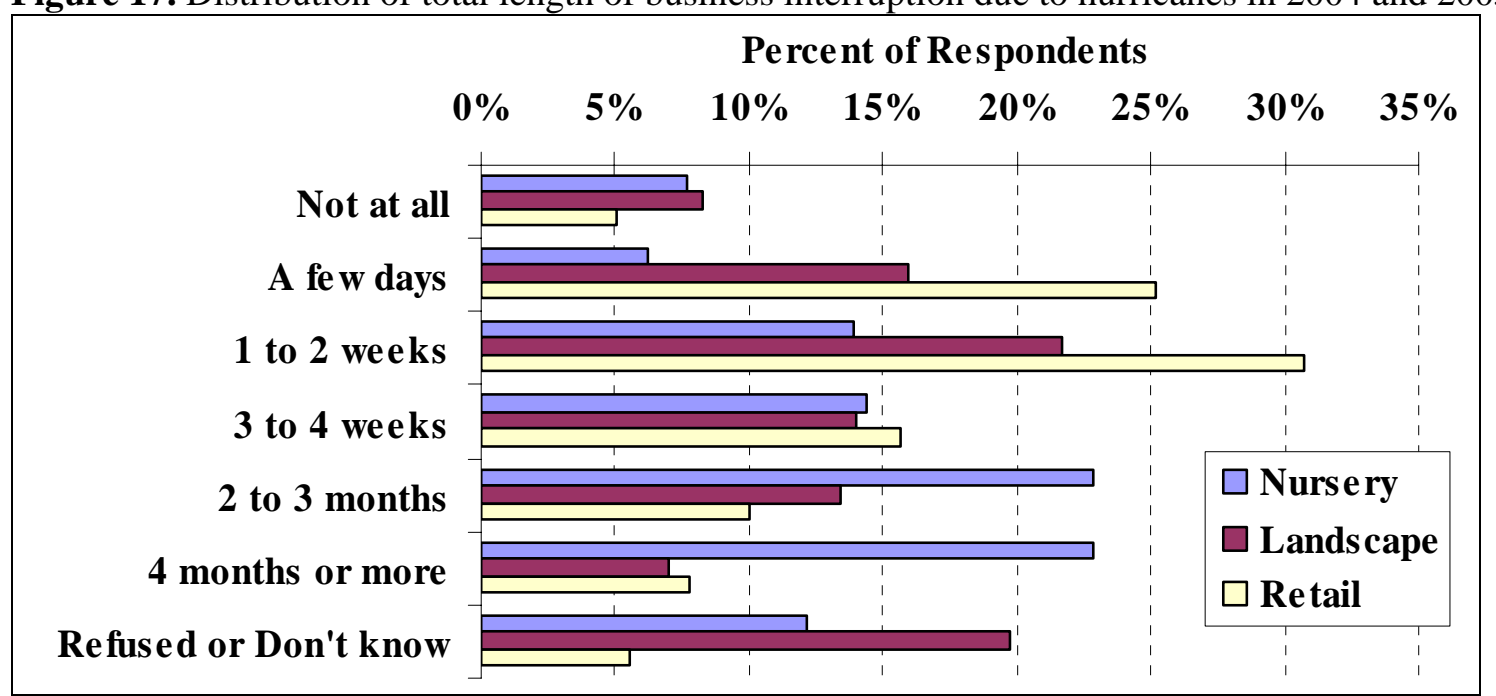

\section{Issues and Threats to the Environmental Horticulture Industry}

Survey respondents were asked to rate possible threats facing the environmental horticulture industry in Florida in terms of "not important", "somewhat important" or "very important". Threats that were rated as "very important" by a majority of respondents were "increasing costs of production" (61\%), "drought, water availability and water use restrictions" (57\%), and "increasing energy costs" (53\%). In addition, "low prices for products" was cited as an important concern of nurseries and retailers, "lack of professionalism” was cited by landscape firms (57\%), and "market power of retail chains" was cited by retailers (Figure 18).

Figure 18. Issues rated as "very important” by survey respondents.

\begin{tabular}{|r|r|r|r|}
\hline & \multicolumn{3}{|c|}{ Percent of Respondents } \\
Incre as ing costs of production \\
Drought, water use restriction \\
Increasing energy costs
\end{tabular}




\section{Financial Borrowing Characteristics and Needs for Wholesale Nurseries}

The financial needs of wholesale nurseries were assessed in this study at the request of the funding partners, and results are summarized in Table 11. Some 41 percent of respondents indicated that they do use credit from financial institutions. Among the reasons considered by managers for choosing a particular financial lender, the most often cited reason was "competitive interest rates", cited by 83 percent of respondents, followed by "convenient/flexible repayment terms" (47\%). Nearly two thirds (63\%) of respondents indicated that they were "very satisfied" with their current lender, 23 percent were "somewhat satisfied", and only 4 percent were "very dissatisfied" or "somewhat dissatisfied".

Respondents were also asked about their anticipated credit needs over the next year. Nearly half (42\%) of firms expected their credit needs to remain the same as the previous year, while 26 percent expected an increased need for credit and 30 percent expected a decreased need for credit. Among the firms reporting credit needs to increase, an increase of 20 percent or more was expected by 40 percent of respondents, while a similar percentage of respondents expected credit needs to decrease by this amount. When asked about their use of electronic banking, 53 percent of respondents indicated that they do use electronic banking and 42 percent did not. Finally, in regard to the issue of electronic applications for loans, 28 percent said they would be interested and 68 percent said they would not be interested. 
Table 11. Financial borrowing characteristics and credit needs of nurseries.

\begin{tabular}{|c|c|c|}
\hline & $\begin{array}{c}\text { Number } \\
\text { Respondents }\end{array}$ & $\begin{array}{c}\text { Percent of } \\
\text { Nursery } \\
\text { Respondents }\end{array}$ \\
\hline \multicolumn{3}{|l|}{ Does Company Borrow Credit? } \\
\hline Yes & 185 & $40.7 \%$ \\
\hline No & 221 & $48.7 \%$ \\
\hline Don't know/Refused & 48 & $10.6 \%$ \\
\hline \multicolumn{3}{|l|}{ Factors for Selecting a Lender } \\
\hline Competitive interest rates & 154 & $83.2 \%$ \\
\hline $\begin{array}{l}\text { Convenient/flexible repayment } \\
\text { terms }\end{array}$ & 87 & $47.0 \%$ \\
\hline Knowledge of the industry & 63 & $34.1 \%$ \\
\hline Operates like a cooperative & 34 & $18.4 \%$ \\
\hline $\begin{array}{l}\text { Long term or personal } \\
\text { relationship with representative }\end{array}$ & 55 & $29.7 \%$ \\
\hline Other reason & 8 & $4.3 \%$ \\
\hline \multicolumn{3}{|l|}{ Satisfaction with Lender } \\
\hline Very satisfied & 117 & $63.2 \%$ \\
\hline Somewhat satisfied & 42 & $22.7 \%$ \\
\hline Neither satisfied nor dissatisfied & 7 & $3.8 \%$ \\
\hline Somewhat dissatisfied & 5 & $2.7 \%$ \\
\hline Very dissatisfied & 2 & $1.1 \%$ \\
\hline \multicolumn{3}{|c|}{ Change in Credit Needs Expected Next Year } \\
\hline Increase & 47 & $26.4 \%$ \\
\hline $1-5 \%$ & 5 & $10.6 \%$ \\
\hline $6-10 \%$ & 4 & $8.5 \%$ \\
\hline $11-15 \%$ & 7 & $14.9 \%$ \\
\hline $16-19 \%$ & 8 & $17.0 \%$ \\
\hline $20 \%$ or more & 19 & $40.4 \%$ \\
\hline Decrease & 53 & $29.8 \%$ \\
\hline $1-5 \%$ & 4 & $7.5 \%$ \\
\hline $6-10 \%$ & 11 & $20.8 \%$ \\
\hline $11-15 \%$ & 3 & $5.7 \%$ \\
\hline $16-19 \%$ & 3 & $5.7 \%$ \\
\hline $20 \%$ or more & 21 & $39.6 \%$ \\
\hline Remain same & 76 & $42.7 \%$ \\
\hline Don't know/Refused & 2 & $1.1 \%$ \\
\hline \multicolumn{3}{|l|}{ Consider Electronic Banking } \\
\hline Yes & 99 & $53.5 \%$ \\
\hline No & 78 & $42.2 \%$ \\
\hline Don't know/Refused & 3 & $1.6 \%$ \\
\hline \multicolumn{3}{|c|}{ Consider Loan Application on Internet } \\
\hline Yes & 51 & $27.6 \%$ \\
\hline No & 126 & $68.1 \%$ \\
\hline Don't know/Refused & 3 & $1.6 \%$ \\
\hline
\end{tabular}




\section{Economic Impact Results}

\section{State Impacts}

The economic impacts of the environmental horticulture industry in Florida were estimated using the Implan input-output regional modeling system, together with survey results for sales, employment, and regional market flows (see Methods). For the nursery and landscape sectors direct output represents industry sales, but for the retail sector, output was calculated as the gross margin on sales (30.5\%). Indirect and induced impacts on nonlocal output (export sales) were calculated using Implan multipliers for Florida (2003).

The total output or revenue impact of the industry in 2005 was estimated at $\$ 12.64$ billion (Bn), including \$10.39 Bn in direct output impacts of industry sales, plus \$100 Mn in indirect impacts from allied firms that supply inputs to the horticulture sectors, and \$2.15 $\mathrm{Bn}$ in induced impacts associated with consumer spending by industry employee households (Table 12). Total output impacts were $\$ 4.77 \mathrm{Bn}$ for nurseries, \$5.27 Bn for landscape services firms, and \$2.60 Bn for horticultural retailers. Nurseries had significant indirect and induced impacts associated with the large nonlocal sales.

The total employment impact of the environmental horticulture industry was estimated at 318,573 jobs, including both fulltime and part-time/seasonal, with 53,551 for nurseries, 88,073 for landscape services, and 176,949 for horticultural retailers (Table 12).

Value added is an important measure of an industry's contribution to a regional economy that represents the difference between sales revenues and the cost of purchased inputs, and includes the value of employee wages and benefits, owner's compensation, dividends, capital outlays and business taxes paid. The total value added impact of Florida’s horticulture industry was $\$ 8.65 \mathrm{Bn}$, including $\$ 3.98 \mathrm{Bn}$ by nurseries, $\$ 2.72 \mathrm{Bn}$ by landscape services and \$1.95 Bn by retailers (Table 12). Total labor income impacts, which are a subset of value added, were $\$ 5.19 \mathrm{Bn}$. The impact on indirect business taxes paid to state and local governments was $\$ 549 \mathrm{Mn}$.

Table 12. Summary of economic impacts of the environmental horticulture industry in Florida, 2005.

\begin{tabular}{|c|c|c|c|c|c|c|c|c|c|}
\hline $\begin{array}{l}\text { Industry } \\
\text { Sector }\end{array}$ & $\begin{array}{l}\text { Direct } \\
\text { Output } \\
\text { (Mn\$) }\end{array}$ & $\begin{array}{l}\text { Non- } \\
\text { Local } \\
\text { Output } \\
(\mathrm{Mn} \$)\end{array}$ & $\begin{array}{l}\text { Indirect } \\
\text { Output } \\
\text { Impact } \\
(\mathrm{Mn} \$)\end{array}$ & $\begin{array}{c}\text { Induced } \\
\text { Output } \\
\text { Impact } \\
(\mathrm{Mn} \$)\end{array}$ & $\begin{array}{l}\text { Total } \\
\text { Output } \\
\text { Impact } \\
(\mathrm{Mn} \$)\end{array}$ & $\begin{array}{c}\text { Employ- } \\
\text { ment } \\
\text { Impact } \\
\text { (jobs) }\end{array}$ & $\begin{array}{l}\text { Value } \\
\text { Added } \\
\text { Impact } \\
(\mathrm{Mn} \$)\end{array}$ & $\begin{array}{l}\text { Labor } \\
\text { Income } \\
\text { Impact } \\
(\mathrm{Mn} \$)\end{array}$ & $\begin{array}{c}\text { Indirect } \\
\text { Business } \\
\text { Tax } \\
\text { Impact } \\
\text { (Mn\$) }\end{array}$ \\
\hline $\begin{array}{l}\text { Nursery \& } \\
\text { Greenhouse }\end{array}$ & $3,007.9$ & $1,270.4$ & 34.7 & $1,725.4$ & 4,768.0 & 53,551 & 3,977.9 & $1,847.9$ & 125.4 \\
\hline $\begin{array}{l}\text { Landscape } \\
\text { Services }\end{array}$ & $5,258.5$ & 9.0 & 3.7 & 10.7 & $5,273.0$ & 88,073 & $2,718.2$ & 2,161.1 & 93.2 \\
\hline $\begin{array}{l}\text { Horticultural } \\
\text { Retailers }\end{array}$ & $2,126.0$ & 290.6 & 61.6 & 408.1 & 2,595.9 & 176,949 & $1,951.7$ & $1,180.3$ & 330.2 \\
\hline Total & $10,391.8$ & $1,570.5$ & 100.1 & $2,145.0$ & $12,636.9$ & 318,573 & $8,647.8$ & $5,189.3$ & 548.8 \\
\hline
\end{tabular}

\section{Comparison with Previous Studies for 1997 and 2000}

In this section, the economic impacts of the Florida environmental horticulture industry in 2005 are compared with results from previous studies for 1997 and 2000 (Table 13). These three studies were all conducted using similar, though not identical methods. All values are expressed in 2005 dollars. Total industry sales increased from $\$ 8.35 \mathrm{Bn}$ in 1997 to $\$ 15.24 \mathrm{Bn}$ in 2005 , which represents a 7.8 percent average annual compound growth rate during the 8 year period. Growth in sales during the 2000-05 period was slightly lower at 6.5 percent annually, suggesting that industry growth may be slowing. Sales growth was highest for the retail sector (11.1\%), followed by landscape services (6.5\%) and nurseries (4.2\%). The total output impact increased from \$8.17 Bn in 1997 to \$12.64 Bn in 2005, representing an average annual growth rate of 5.6 percent. Total employment impacts more than doubled between 1997 and 2005, from 158 to 318 thousand jobs, growing 9.2 percent annually. This large increase was mainly driven by the retail sector, while employment in the landscape sector was essentially flat. Total value added impacts increased from \$5.97 to \$8.65 Bn, or 4.7 percent annually, as charted in Figure 19. 
Figure 19. Trend in value added impacts of the Florida environmental horticulture industry, 1997 to 2005.

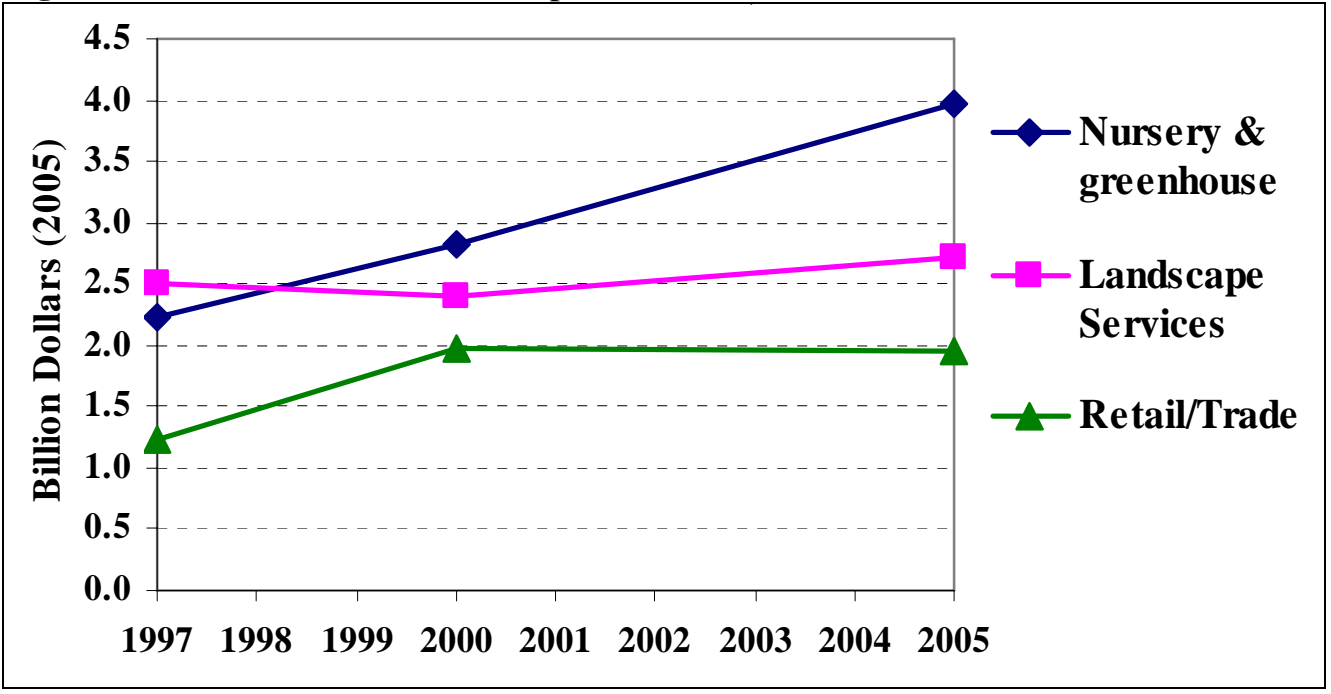

Table 13. Economic impacts of the Florida environmental horticulture industry in 1997, 2000 and 2005.

\begin{tabular}{|c|c|c|c|c|}
\hline Impact / Sector & 2005 & $2000 *$ & $1997 *$ & $\begin{array}{c}\text { Average } \\
\text { Annual } \\
\text { Compound } \\
\text { Growth Rate } \\
\text { 1997-2005 }\end{array}$ \\
\hline Sales (million \$) & 15,237 & 11,120 & 8,353 & $7.8 \%$ \\
\hline Production (nursery \& greenhouse) & 3,007 & 2,526 & 2,164 & $4.2 \%$ \\
\hline Landscape Services & 5,259 & 3,491 & 3,185 & $6.5 \%$ \\
\hline Retail/Trade & 6,971 & 5,103 & 3,005 & $11.1 \%$ \\
\hline Direct Output (million \$) & 10,392 & 7,735 & 6,424 & $6.2 \%$ \\
\hline Production (nursery \& greenhouse) & 3,007 & 2,526 & 2,164 & $4.2 \%$ \\
\hline Landscape Services & 5,259 & 3,491 & 3,185 & $6.5 \%$ \\
\hline Retail/Trade & 2,126 & 1,718 & 1,075 & $8.9 \%$ \\
\hline Output Impacts (million \$) & 12,637 & 10,285 & 8,173 & $5.6 \%$ \\
\hline Production (nursery \& greenhouse) & 4,768 & 3,901 & 3,145 & $5.3 \%$ \\
\hline Landscape Services & 5,273 & 3,810 & 3,350 & $5.8 \%$ \\
\hline Retail/Trade & 2,596 & 2,574 & 1,678 & $5.6 \%$ \\
\hline Value Added Impacts (million \$) & 8,648 & 7,184 & 5,973 & $4.7 \%$ \\
\hline Production (nursery \& greenhouse) & 3,978 & 2,826 & 2,238 & $7.5 \%$ \\
\hline Landscape Services & 2,718 & 2,391 & 2,502 & $1.0 \%$ \\
\hline Retail/Trade & 1,952 & 1,968 & 1,234 & $5.9 \%$ \\
\hline Labor Income Impacts (million \$) & 5,189 & 4,622 & 3,931 & $3.5 \%$ \\
\hline Production (nursery \& greenhouse) & 1,848 & 1,805 & 1,208 & $5.5 \%$ \\
\hline Landscape Services & 2,161 & 1,592 & 1,931 & $1.4 \%$ \\
\hline Retail/Trade & 1,180 & 1,227 & 792 & $5.1 \%$ \\
\hline Indirect Business Tax Impacts (million \$) & 549 & 519 & 356 & $5.6 \%$ \\
\hline Production (nursery \& greenhouse) & 125 & 101 & 67 & $8.1 \%$ \\
\hline Landscape Services & 93 & 106 & 91 & $0.4 \%$ \\
\hline Retail/Trade & 330 & 312 & 198 & $6.6 \%$ \\
\hline Employment Impacts (jobs) & 318,573 & 187,860 & 157,950 & $9.2 \%$ \\
\hline Production (nursery \& greenhouse) & 53,551 & 54,288 & 44,892 & $2.2 \%$ \\
\hline Landscape Services & 88,073 & 64,282 & 89,517 & $-0.4 \%$ \\
\hline Retail/Trade & 176,949 & 69,290 & 23,541 & $28.7 \%$ \\
\hline
\end{tabular}




\section{Regional and County Economic Impacts}

Economic impacts of the Florida environmental horticulture industry in 2005 were estimated for individual counties by allocating total statewide impacts in relation to county-level direct employment reported by the Florida Department of Labor (see Methods section). County level impacts are summarized in Tables 14 and 15 and Figure 20. Total industry sales exceeded a billion dollars in the counties of Miami-Dade (\$1.98 Bn), Palm Beach (\$1.18 Bn), Orange (\$1.14 Bn) and Hillsborough (\$1.01 Bn). Total output impacts were highest in the counties of Miami-Dade (\$1.87 Bn), Orange (\$1.19 Bn), Palm Beach (\$1.04 Bn), Hillsborough ( $\$ 905 \mathrm{Mn}$ ), Broward (\$725 Mn), Volusia (\$582 Mn), Duval (\$457 Mn), Lee (\$455 Mn), Lake (\$405 Mn), Pinellas (\$348 Mn), Collier (\$330 Mn), Polk (\$315 Mn), and Seminole (\$301 Mn). Total employment impacts were highest in the same counties, but in a slightly different order: Miami-Dade (40,837 jobs), Palm Beach (23,776), Orange (21,733), Hillsborough (20,410), Broward (18,157), Duval (11,768), Volusia $(10,454)$, Pinellas $(10,208)$, Lee $(10,162)$, Lake $(9,814)$, Polk $(9,532)$, Collier $(9,030)$, and Seminole $(9,031)$, as shown in Figure 20. Value added impacts in the top six counties were: Miami-Dade (\$1.37 Bn), Orange ( $\$ 825 \mathrm{Mn}$ ), Palm Beach (\$684 Mn), Hillsborough ( $\$ 610 \mathrm{Mn})$, Volusia ( $\$ 448 \mathrm{Mn})$, and Broward (\$434 $\mathrm{Mn})$.

In the nursery sector, county level employment impacts were greatest in Miami-Dade (11,741 jobs), Orange (6,668), Volusia (4,740), Hillsborough $(3,925)$, and Palm Beach $(3,873)$. In the landscape services sector, county level employment impacts were highest in Palm Beach (8,954 jobs), Miami-Dade (8,716), Broward $(8,388)$, Orange $(8,290)$, and Hillsborough $(6,939)$. In the horticultural retailing sector county-level employment impacts were highest in Miami-Dade (20,380 jobs), Palm Beach (10,949), Hillsborough $(9,546)$, Broward $(8,694)$, and Orange $(6,776)$.

Figure 20. Employment impacts of the environmental horticulture industry in the top 20 Florida counties, 2005.

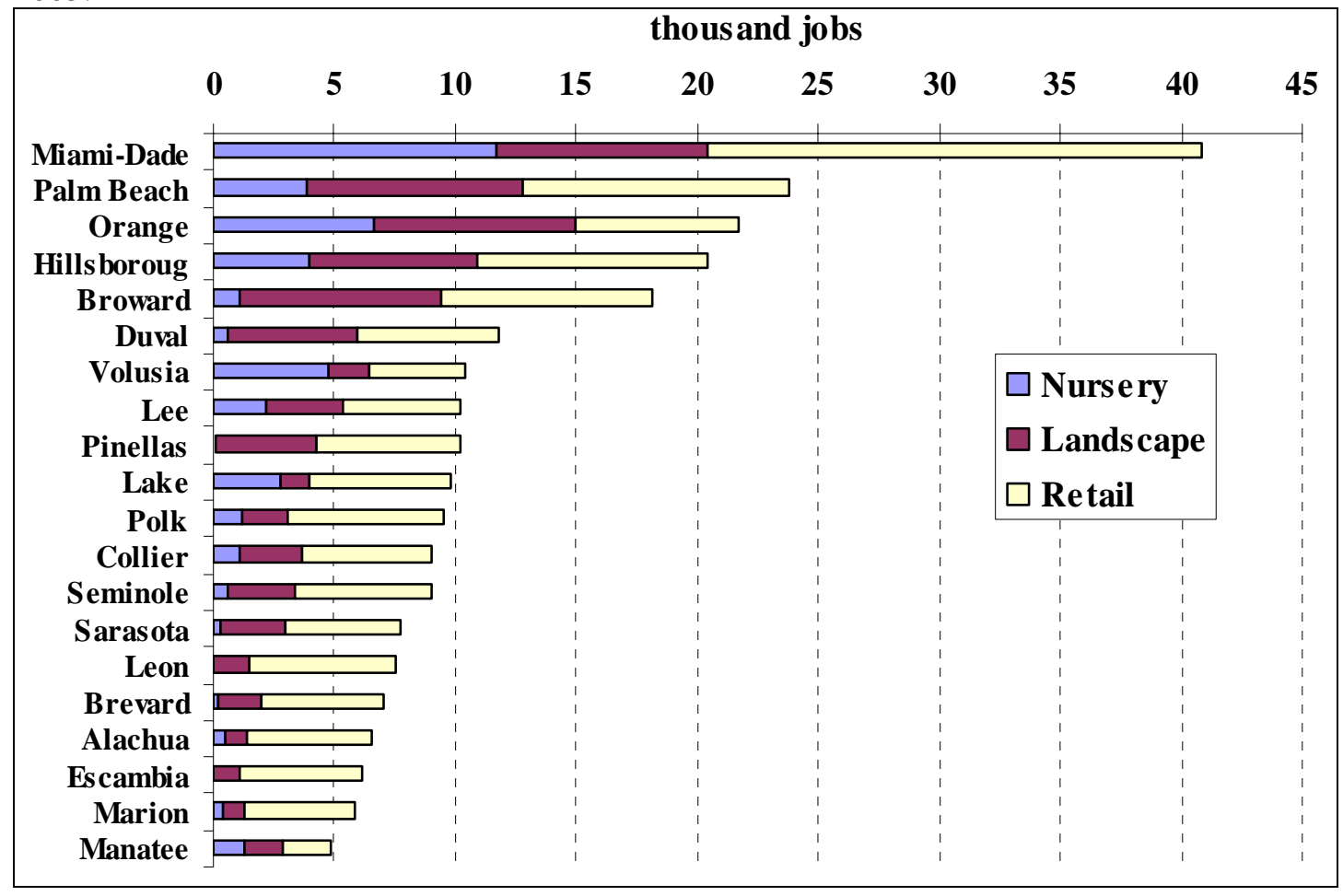


Table 14. Sales and output impacts of the environmental horticulture industry in Florida counties, 2005.

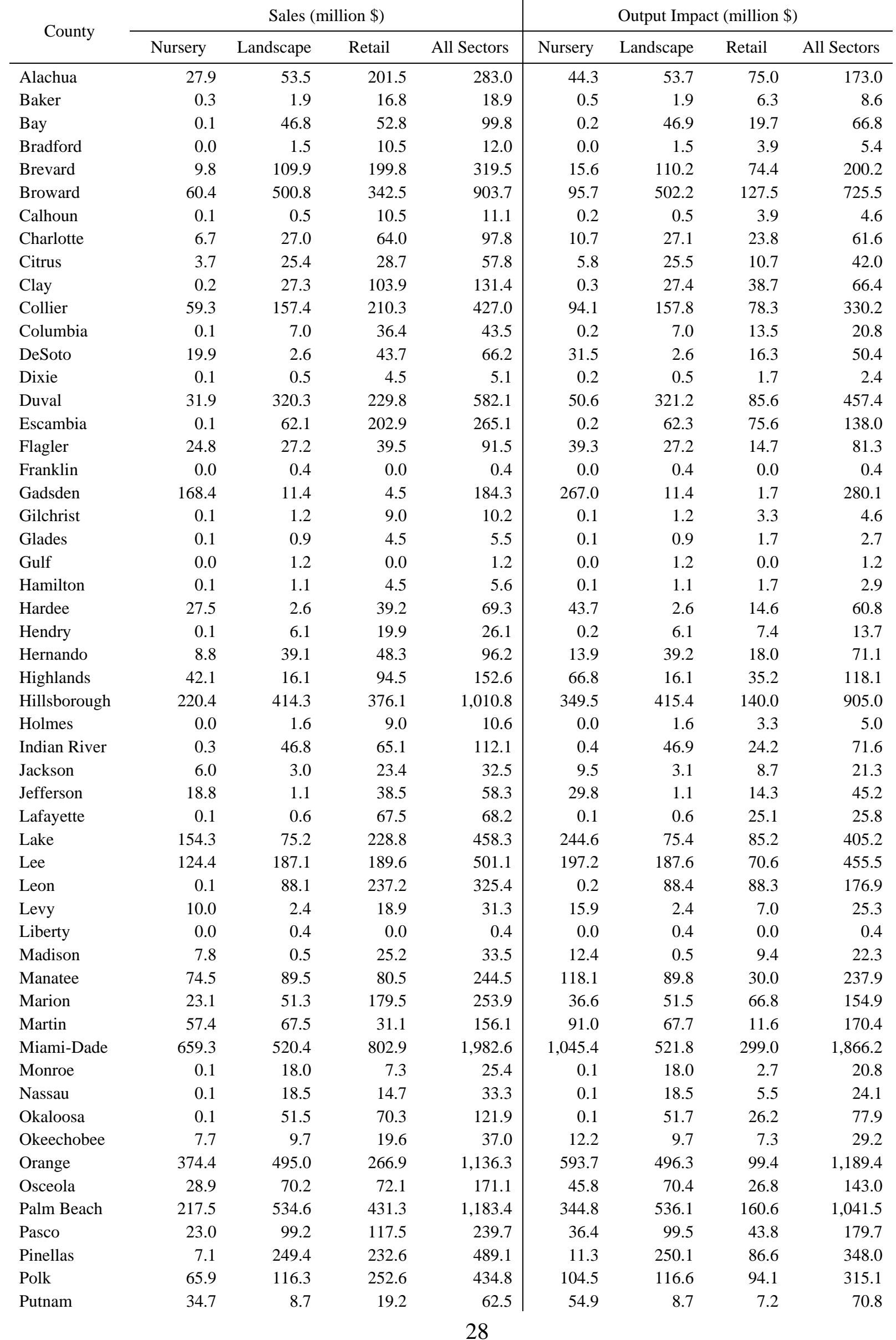




\begin{tabular}{lrrrr|rrrr} 
& \multicolumn{4}{c}{ Sales (million \$) } & \multicolumn{3}{c}{ Output Impact (million \$) } \\
\cline { 2 - 9 } County & Nursery & Landscape & \multicolumn{1}{c}{ Retail } & All Sectors & Nursery & Landscape & Retail & All Sectors \\
\hline St. Johns & 17.8 & 35.6 & 173.5 & 226.8 & 28.2 & 35.7 & 64.6 & 128.4 \\
St. Lucie & 21.4 & 59.2 & 143.8 & 224.4 & 33.9 & 59.3 & 53.5 & 146.8 \\
Santa Rosa & 9.3 & 29.3 & 34.6 & 73.2 & 14.7 & 29.4 & 12.9 & 57.0 \\
Sarasota & 14.3 & 161.1 & 190.0 & 365.4 & 22.7 & 161.6 & 70.7 & 255.1 \\
Seminole & 34.3 & 162.9 & 224.2 & 421.4 & 54.4 & 163.3 & 83.5 & 301.2 \\
Sumter & 28.2 & 4.8 & 20.3 & 53.2 & 44.7 & 4.8 & 7.6 & 57.0 \\
Suwannee & 5.1 & 5.1 & 53.5 & 63.7 & 8.1 & 5.1 & 19.9 & 33.1 \\
Taylor & 0.1 & 2.5 & 9.0 & 11.6 & 0.2 & 2.5 & 3.3 & 6.1 \\
Union & 0.1 & 1.5 & 4.5 & 6.0 & 0.1 & 1.5 & 1.7 & 3.3 \\
Volusia & 266.2 & 100.4 & 158.8 & 525.4 & 422.0 & 100.7 & 59.1 & 581.9 \\
Wakulla & 0.1 & 3.7 & 4.5 & 8.3 & 0.1 & 3.7 & 1.7 & 5.5 \\
Walton & 0.1 & 18.8 & 45.1 & 64.0 & 0.1 & 18.9 & 16.8 & 35.8 \\
Washington & 1.6 & 1.3 & 9.0 & 12.0 & 2.6 & 1.3 & 3.3 & 7.3 \\
\hline Total & 3,007 & 5,259 & 6,971 & 15,237 & $4,768.0$ & $5,273.0$ & $2,595.9$ & $12,636.9$ \\
\hline
\end{tabular}


Table 15. Employment and value added impacts of the environmental horticulture industry in Florida counties, 2005.

\begin{tabular}{|c|c|c|c|c|c|c|c|c|}
\hline \multirow{2}{*}{ County } & \multicolumn{4}{|c|}{ Employment Impact (jobs) } & \multicolumn{4}{|c|}{ Value Added Impact (million \$) } \\
\hline & Nursery & Landscape & Retail & All Sectors & Nursery & Landscape & Retail & All Sectors \\
\hline Alachua & 497 & 896 & 5,115 & 6,509 & 37.0 & 27.7 & 56.4 & 121.0 \\
\hline Baker & 5 & 31 & 426 & 462 & 0.4 & 1.0 & 4.7 & 6.0 \\
\hline Bay & 2 & 784 & 1,341 & 2,127 & 0.2 & 24.2 & 14.8 & 39.2 \\
\hline Bradford & 0 & 25 & 266 & 291 & 0.0 & 0.8 & 2.9 & 3.7 \\
\hline Brevard & 175 & 1,841 & 5,071 & 7,086 & 13.0 & 56.8 & 55.9 & 125.7 \\
\hline Broward & 1,075 & 8,388 & 8,694 & 18,157 & 79.8 & 258.9 & 95.9 & 434.6 \\
\hline Calhoun & 2 & 8 & 266 & 277 & 0.2 & 0.3 & 2.9 & 3.4 \\
\hline Charlotte & 120 & 453 & 1,625 & 2,197 & 8.9 & 14.0 & 17.9 & 40.8 \\
\hline Citrus & 66 & 426 & 728 & 1,219 & 4.9 & 13.1 & 8.0 & 26.0 \\
\hline Clay & 3 & 458 & 2,637 & 3,098 & 0.2 & 14.1 & 29.1 & 43.5 \\
\hline Collier & 1,056 & 2,636 & 5,337 & 9,030 & 78.5 & 81.4 & 58.9 & 218.7 \\
\hline Columbia & 2 & 117 & 924 & 1,043 & 0.2 & 3.6 & 10.2 & 14.0 \\
\hline DeSoto & 354 & 43 & 1,110 & 1,507 & 26.3 & 1.3 & 12.2 & 39.9 \\
\hline Dixie & 2 & 8 & 114 & 125 & 0.2 & 0.2 & 1.3 & 1.7 \\
\hline Duval & 569 & 5,365 & 5,834 & 11,768 & 42.2 & 165.6 & 64.4 & 272.2 \\
\hline Escambia & 2 & 1,040 & 5,151 & 6,193 & 0.2 & 32.1 & 56.8 & 89.1 \\
\hline Flagler & 442 & 455 & 1,003 & 1,900 & 32.8 & 14.0 & 11.1 & 57.9 \\
\hline Franklin & 0 & 6 & 0 & 6 & 0.0 & 0.2 & 0.0 & 0.2 \\
\hline Gadsden & 2,999 & 190 & 114 & 3,304 & 222.8 & 5.9 & 1.3 & 229.9 \\
\hline Gilchrist & 1 & 20 & 228 & 249 & 0.1 & 0.6 & 2.5 & 3.2 \\
\hline Glades & 1 & 15 & 114 & 131 & 0.1 & 0.5 & 1.3 & 1.8 \\
\hline Gulf & 0 & 20 & 0 & 20 & 0.0 & 0.6 & 0.0 & 0.6 \\
\hline Hamilton & 1 & 18 & 114 & 133 & 0.1 & 0.6 & 1.3 & 1.9 \\
\hline Hardee & 491 & 43 & 995 & 1,528 & 36.4 & 1.3 & 11.0 & 48.7 \\
\hline Hendry & 2 & 102 & 506 & 610 & 0.2 & 3.1 & 5.6 & 8.9 \\
\hline Hernando & 156 & 655 & 1,225 & 2,037 & 11.6 & 20.2 & 13.5 & 45.4 \\
\hline Highlands & 750 & 269 & 2,398 & 3,417 & 55.7 & 8.3 & 26.4 & 90.5 \\
\hline Hillsborough & 3,925 & 6,939 & 9,546 & 20,410 & 291.6 & 214.2 & 105.3 & 611.0 \\
\hline Holmes & 0 & 27 & 228 & 255 & 0.0 & 0.8 & 2.5 & 3.3 \\
\hline Indian River & 5 & 784 & 1,652 & 2,440 & 0.4 & 24.2 & 18.2 & 42.8 \\
\hline Jackson & 107 & 51 & 595 & 753 & 7.9 & 1.6 & 6.6 & 16.1 \\
\hline Jefferson & 335 & 18 & 977 & 1,329 & 24.9 & 0.5 & 10.8 & 36.2 \\
\hline Lafayette & 1 & 10 & 1,714 & 1,725 & 0.1 & 0.3 & 18.9 & 19.3 \\
\hline Lake & 2,747 & 1,259 & 5,808 & 9,814 & 204.1 & 38.9 & 64.1 & 307.0 \\
\hline Lee & 2,215 & 3,133 & 4,813 & 10,162 & 164.6 & 96.7 & 53.1 & 314.4 \\
\hline Leon & 2 & 1,476 & 6,021 & 7,499 & 0.2 & 45.6 & 66.4 & 112.1 \\
\hline Levy & 179 & 40 & 480 & 698 & 13.3 & 1.2 & 5.3 & 19.8 \\
\hline Liberty & 0 & 6 & 0 & 6 & 0.0 & 0.2 & 0.0 & 0.2 \\
\hline Madison & 139 & 8 & 639 & 787 & 10.3 & 0.3 & 7.1 & 17.6 \\
\hline Manatee & 1,327 & 1,500 & 2,042 & 4,869 & 98.6 & 46.3 & 22.5 & 167.4 \\
\hline Marion & 411 & 860 & 4,556 & 5,827 & 30.5 & 26.5 & 50.2 & 107.3 \\
\hline Martin & 1,023 & 1,131 & 790 & 2,944 & 76.0 & 34.9 & 8.7 & 119.6 \\
\hline Miami-Dade & 11,741 & 8,716 & 20,380 & 40,837 & 872.1 & 269.0 & 224.8 & $1,365.9$ \\
\hline Monroe & 1 & 301 & 186 & 488 & 0.1 & 9.3 & 2.1 & 11.4 \\
\hline Nassau & 2 & 309 & 373 & 684 & 0.1 & 9.5 & 4.1 & 13.8 \\
\hline Okaloosa & 1 & 863 & 1,785 & 2,649 & 0.1 & 26.6 & 19.7 & 46.4 \\
\hline Okeechobee & 137 & 162 & 497 & 796 & 10.2 & 5.0 & 5.5 & 20.7 \\
\hline Orange & 6,668 & 8,290 & 6,776 & 21,733 & 495.3 & 255.9 & 74.7 & 825.9 \\
\hline Osceola & 514 & 1,175 & 1,829 & 3,519 & 38.2 & 36.3 & 20.2 & 94.6 \\
\hline Palm Beach & 3,873 & 8,954 & 10,949 & 23,776 & 287.7 & 276.4 & 120.8 & 684.8 \\
\hline Pasco & 409 & 1,662 & 2,984 & 5,055 & 30.4 & 51.3 & 32.9 & 114.6 \\
\hline Pinellas & 127 & 4,177 & 5,905 & 10,208 & 9.4 & 128.9 & 65.1 & 203.4 \\
\hline Polk & 1,173 & 1,948 & 6,412 & 9,532 & 87.1 & 60.1 & 70.7 & 218.0 \\
\hline
\end{tabular}




\begin{tabular}{|c|c|c|c|c|c|c|c|c|}
\hline \multirow{2}{*}{ County } & \multicolumn{4}{|c|}{ Employment Impact (jobs) } & \multicolumn{4}{|c|}{ Value Added Impact (million \$) } \\
\hline & Nursery & Landscape & Retail & All Sectors & Nursery & Landscape & Retail & All Sectors \\
\hline Putnam & 617 & 145 & 488 & 1,250 & 45.8 & 4.5 & 5.4 & 55.7 \\
\hline St. Johns & 316 & 596 & 4,405 & 5,317 & 23.5 & 18.4 & 48.6 & 90.5 \\
\hline St. Lucie & 381 & 991 & 3,650 & 5,022 & 28.3 & 30.6 & 40.3 & 99.2 \\
\hline Santa Rosa & 165 & 491 & 879 & 1,535 & 12.3 & 15.1 & 9.7 & 37.1 \\
\hline Sarasota & 255 & 2,699 & 4,822 & 7,776 & 19.0 & 83.3 & 53.2 & 155.4 \\
\hline Seminole & 611 & 2,728 & 5,692 & 9,031 & 45.4 & 84.2 & 62.8 & 192.3 \\
\hline Sumter & 501 & 80 & 515 & 1,097 & 37.3 & 2.5 & 5.7 & 45.4 \\
\hline Suwannee & 91 & 85 & 1,359 & 1,535 & 6.8 & 2.6 & 15.0 & 24.4 \\
\hline Taylor & 2 & 42 & 228 & 272 & 0.2 & 1.3 & 2.5 & 4.0 \\
\hline Union & 1 & 25 & 114 & 140 & 0.1 & 0.8 & 1.3 & 2.1 \\
\hline Volusia & 4,740 & 1,682 & 4,032 & 10,454 & 352.1 & 51.9 & 44.5 & 448.5 \\
\hline Wakulla & 2 & 62 & 114 & 178 & 0.1 & 1.9 & 1.3 & 3.3 \\
\hline Walton & 1 & 315 & 1,146 & 1,462 & 0.1 & 9.7 & 12.6 & 22.5 \\
\hline Washington & 29 & 22 & 228 & 280 & 2.2 & 0.7 & 2.5 & 5.4 \\
\hline Total & 53,551 & 88,073 & 176,949 & 318,573 & $3,977.9$ & $2,718.2$ & $1,951.7$ & $8,647.8$ \\
\hline
\end{tabular}

Economic impacts were also summarized by regions corresponding to functional economic areas, as defined by the US Bureau of Economic Analysis based on employee commuting patterns reported in the 2000 Census of population and housing ${ }^{9}$. A map of the regions is shown in Figure 21 and regional economic impacts are summarized in Table 16 and Figure 22. Output impacts were highest in the Miami-Ft Lauderdale region (\$4.09 Bn), followed by Orlando (\$3.65 Bn), Tampa-St. Petersburg (\$1.50 Bn), Sarasota-Bradenton (\$1.39 Bn), Jacksonville (\$756 Mn), Tallahassee (\$540 Mn), Pensacola (\$309 Mn), Gainesville (\$294 Mn) and Panama City (\$106 Mn). Regional employment impacts followed in a slightly different order: Miami-Ft Lauderdale (95,202 jobs), Orlando (86,157), Tampa-St. Petersburg (37,711), Sarasota-Bradenton (35,541), Jacksonville $(22,580)$, Tallahassee $(13,515)$, Gainesville $(12,315)$, Pensacola $(11,839)$, and Panama City $(3,713)$, as shown in Figure 22. Value added impacts exceeded \$2 Bn in the Miami-Ft. Lauderdale region $(\$ 2.79 \mathrm{Bn})$ and Orlando region (\$2.59 Bn).

Figure 21. Map of economic regions of Florida.

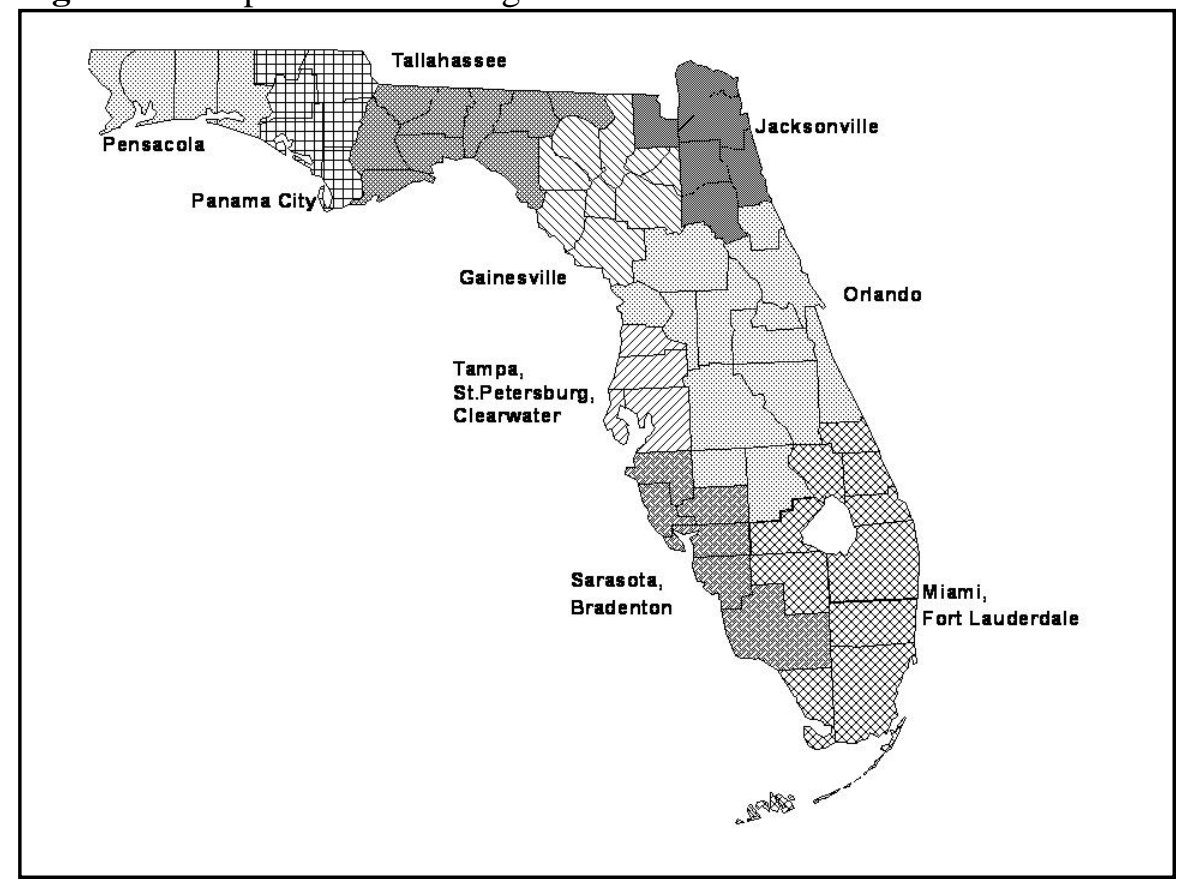

${ }^{9}$ Johnson, K. and J. Kort. Redefinition of the BEA Economic Areas. Survey of Current Business, pp.68-75, Nov. 2004. Bureau of Economic Analysis, U.S. Department of Commerce, Washington, D.C. 
Figure 22. Employment impacts of the environmental horticulture industry in Florida regions, 2005.

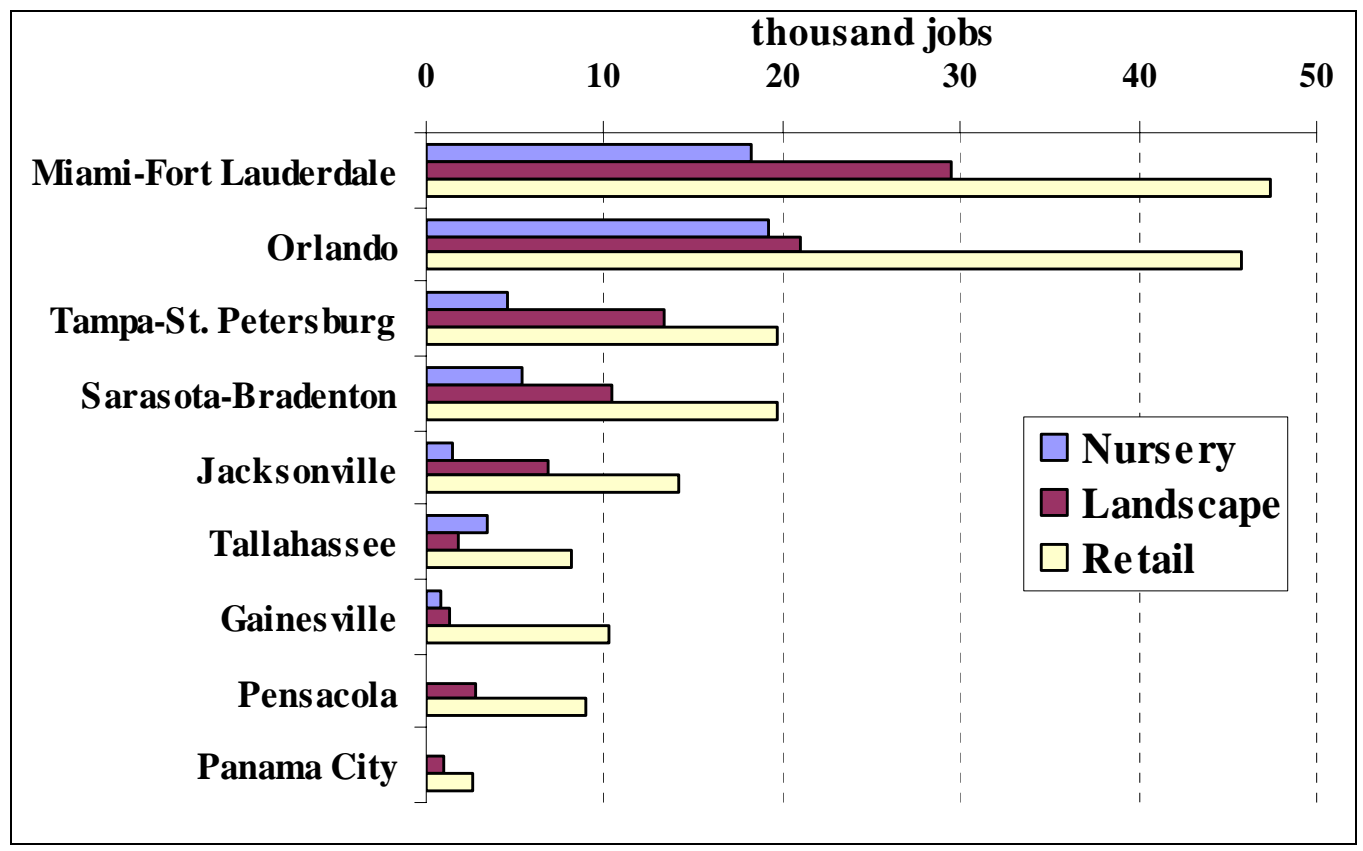

Table 16. Regional economic impacts of the environmental horticulture industry in Florida, 2005.

\begin{tabular}{|c|c|c|c|c|c|c|c|c|c|c|}
\hline Sector & $\begin{array}{l}\text { Gaines- } \\
\text { ville }\end{array}$ & $\begin{array}{l}\text { Jackson- } \\
\text { ville }\end{array}$ & $\begin{array}{l}\text { Miami- } \\
\text { Fort } \\
\text { Lauder- } \\
\text { dale } \\
\end{array}$ & Orlando & $\begin{array}{l}\text { Panama } \\
\text { City }\end{array}$ & Pensacola & $\begin{array}{l}\text { Sarasota- } \\
\text { Bradenton }\end{array}$ & $\begin{array}{l}\text { Talla- } \\
\text { hassee }\end{array}$ & $\begin{array}{l}\text { Tampa-St. } \\
\text { Peters- } \\
\text { burg }\end{array}$ & $\begin{array}{l}\text { Total All } \\
\text { Regions }\end{array}$ \\
\hline \multicolumn{11}{|c|}{ Sales (million \$) } \\
\hline Nursery & 43.6 & 84.9 & $1,024.2$ & $1,083.1$ & 7.9 & 9.5 & 299.2 & 195.4 & 259.3 & $3,007.2$ \\
\hline Landscape & 73.2 & 412.2 & $1,763.9$ & $1,257.1$ & 54.5 & 161.8 & 624.8 & 109.0 & 802.0 & $5,258.5$ \\
\hline Retail & 406.3 & 558.0 & $1,868.1$ & $1,804.8$ & 104.8 & 353.0 & 778.0 & 323.3 & 774.5 & $6,970.9$ \\
\hline All Sectors & 523.1 & $1,055.1$ & $4,656.2$ & $4,145.1$ & 167.2 & 524.3 & $1,702.0$ & 627.8 & $1,835.8$ & $15,236.5$ \\
\hline \multicolumn{11}{|c|}{ Output Impact (million \$) } \\
\hline Nursery & 69.1 & 134.6 & $1,623.9$ & $1,717.4$ & 12.6 & 15.1 & 474.4 & 309.9 & 411.1 & $4,768.0$ \\
\hline Landscape & 73.4 & 413.3 & $1,768.8$ & $1,260.6$ & 54.7 & 162.2 & 626.5 & 109.3 & 804.2 & $5,273.0$ \\
\hline Retail & 151.3 & 207.8 & 695.7 & 672.1 & 39.0 & 131.4 & 289.7 & 120.4 & 288.4 & $2,595.9$ \\
\hline All Sectors & 293.8 & 755.7 & $4,088.4$ & $3,650.1$ & 106.2 & 308.7 & $1,390.6$ & 539.7 & $1,503.7$ & $12,636.9$ \\
\hline \multicolumn{11}{|c|}{ Value Added Impact (million\$) } \\
\hline Nursery & 57.7 & 112.3 & $1,354.8$ & $1,432.8$ & 10.5 & 12.6 & 395.8 & 258.5 & 343.0 & $3,977.9$ \\
\hline Landscape & 37.8 & 213.1 & 911.8 & 649.8 & 28.2 & 83.6 & 323.0 & 56.4 & 414.6 & $2,718.2$ \\
\hline Retail & 113.8 & 156.2 & 523.0 & 505.3 & 29.3 & 98.8 & 217.8 & 90.5 & 216.9 & $1,951.7$ \\
\hline All Sectors & 209.2 & 481.6 & 2,789.6 & $2,587.9$ & 68.0 & 195.0 & 936.5 & 405.4 & 974.4 & $8,647.8$ \\
\hline \multicolumn{11}{|c|}{ Employment Impact (jobs) } \\
\hline Nursery & 776 & 1,512 & 18,239 & 19,288 & 141 & 170 & 5,328 & 3,481 & 4,617 & 53,551 \\
\hline Landscape & 1,225 & 6,904 & 29,543 & 21,055 & 913 & 2,709 & 10,464 & 1,826 & 13,433 & 88,073 \\
\hline Retail & 10,314 & 14,164 & 47,420 & 45,813 & 2,659 & 8,960 & 19,750 & 8,208 & 19,661 & 176,949 \\
\hline All Sectors & 12,315 & 22,580 & 95,202 & 86,157 & 3,713 & 11,839 & 35,541 & 13,515 & 37,711 & 318,573 \\
\hline
\end{tabular}




\section{Impacts on Allied Suppliers for Nursery Producers}

The nursery and greenhouse industry purchases large volumes of supplies for production from allied vendors. The value of inputs to the nursery sector were estimated based on total sales for 2005, together with information on typical operating expenses ${ }^{10}$, as shown in Table 17. Total inputs purchased (excluding labor), were estimated at \$821 Mn, which represented 27 percent of total sales (3.0 Bn). The largest expense item was for plants and seeds ( $\$ 292 \mathrm{Mn}$ ), much of which was purchased from other nursery growers. Other expense items included \$147 Mn in growing containers, \$101 Mn in growing media, \$82 Mn in packaging materials, \$81 Mn in fertilizer/lime, and \$65 Mn in chemicals (pesticides, growth regulators, etc.), and \$53 $\mathrm{Mn}$ in miscellaneous other supplies.

Table 17. Estimated purchases of supplies by the nursery and greenhouse industry in Florida, 2005.

\begin{tabular}{lcr} 
Expense Item & $\begin{array}{c}\text { Cost as } \\
\text { Percent of } \\
\text { Sales }\end{array}$ & $\begin{array}{c}\text { Total } \\
\text { Purchases } \\
(\$ 1000)\end{array}$ \\
\hline Plants and seeds & $9.7 \%$ & 292,372 \\
Containers & $4.9 \%$ & 147,095 \\
Growing media & $3.4 \%$ & 100,767 \\
Fertilizer and lime & $2.7 \%$ & 81,055 \\
Chemicals & $2.2 \%$ & 65,319 \\
Packaging & $2.7 \%$ & 81,510 \\
Other supplies & $1.8 \%$ & 53,115 \\
\hline Total expenses & $27.3 \%$ & 821,232 \\
\hline
\end{tabular}

\section{Conclusions}

In this study, telephone and internet surveys were used to document industry sales and employment in 2005 for Florida nursery growers, landscape service firms and horticultural retailers, and a regional economic model was used to evaluate total economic impacts on the state's economy. This research demonstrated that the environmental horticulture industry in Florida has continued to grow rapidly during the period of 2000 through 2005, presumably driven by strong population growth and housing development. Growth was particularly strong for the retail sector. Industry sales and employment estimated from survey data were significantly higher than published values based on secondary statistics, due to better coverage of many small and undocumented firms. The nursery production sector has significant indirect and induced impacts on other sectors of the economy associated with sales of plant products to out-of-state markets that bring new money into the state. Total employment impacts of the environmental horticulture industry in Florida were significantly greater than for other major agricultural commodities such as forest products and fruits/vegetables, while total output and value added impacts were comparable. Unlike many other agricultural industries, economic activity in environmental horticulture in Florida tends to be concentrated in urban areas, close to the workforce and markets for landscape services and retail goods. The economic impacts of the environmental horticulture industry occurred in spite of the staggering product losses, structural damages, cleanup costs, and business interruption suffered from hurricanes in 2004 and 2005.

\footnotetext{
${ }^{10}$ Hodges, A.W., L.N. Satterthwaite and J.J. Haydu. Business Analysis of Ornamental Plant Nurseries in Florida, 1998. Economic Information Report 00-5r, University of Florida/IFAS, Food \& Resource Economics Department, Feb. 2001. Available at http://hortbusiness.ifas.ufl.edu/EIR00-5r.pdf.
} 


\section{Appendix: Telephone Survey Questionnaire}

Question HELLO. Hello, my name is I'm calling from the University of Florida. May I speak with an owner, manager or person in charge of the business at this office? INTERVIEWER: PRESS 1 TO CONTINUE WITH SURVEY. IF ELIGIBLE RESPONDENT IS NOT AVAILABLE, ARRANGE A CALLBACK. PRESS CTRL/END TO TERMINATE CALL. Hello, this is from the

University of Florida. This is not a sales call.

(NOTE TO INT: THIS CALL COULD BE A PARTIAL-COMPLETE) INTERVIEWER: PRESS 1 TO CONTINUE SURVEY

Question INTRO. The University of Florida is conducting a 10 minute environmental horticulture industry survey sponsored by the Florida Nursery Growers and Landscape Association. Your participation is voluntary, you don't have to answer any question you don't want to, and all your answer will be confidential. (INT: READ ANY OF THE FOLLOWING IF NEEDED: The purpose of this survey is to evaluate the economic impacts of the industry. We are collecting information on the types of products and services provided, annual sales, employment, regional trade, marketing channels, threats to the industry, and the effects of hurricanes. Your answers are confidential; only averages or totals for all survey respondents will be disclosed. It is important that you provide information so that your type of business is represented in the study.) (INT: PRESS 1 TO CONTINUE)

Question CONSENT. Do you consent to participate in the survey?

1 Yes

2 No

Question EXIT. Thank you for your time. (INT: PRESS ANY KEY TO EXIT SURVEY. CODE AS EITHER A SOFT REFUSAL OR A STRONG REFUSAL BASED ON WHAT HAPPENED DURING THE CALL)

Question QUAL. Did this business produce and sell ornamental plants in 2005?

1 Yes

2 No

-8 Don't know

-9 Refused

Question EXIT1. Today we are only interviewing businesses that produced and sold ornamental plants in 2005. Thank you for your time. INT: PRESS ANY KEY TO END THE SURVEY. THIS WILL BE AUTOCODED AS NO ELIGIBLE RESPONDENT)

Question QUALIF. Today we are only interviewing businesses that produced and sold ornamental plants in 2005. Thank you for your time. (INT: PRESS ANY
KEY TO END THE SURVEY. THIS WILL BE AUTOCODED AS NO ELIGIBLE RESPONDENT)

Question POSITION. What is your position in this organization?

Owner

Manager

$\mathrm{CEO}, \mathrm{CFO}$ or $\mathrm{COO}$

Administrative assistant or company employee

Other (please specify)

Don't know

Refused

Question HOWLONG. How many years has this company been in business?

(0-100)

-8 Don't know

-9 Refused

Question PRODUCT. What was the net area, in square feet, used by your business in 2005 for greenhouse or shadehouse production?

1 None (not applicable)

2 Less than 10 thousand

310 to 49 thousand

450 to 99 thousand

5100 to 199 thousand

6200 to 499 thousand

7500 to 999 thousand

81 million or more

-8 Don't know

-9 Refused

Question MILLION. Please specify amount to nearest one-tenth million sq.ft (INT: Read if needed: One million one hundred thousand square feet would be 1.1 million.)

$(0.0-100.0)$

-8 Don't know

-9 Refused

Question OPEN. What was the net area used, in acres, by your business in 2005 for open container plant production?

(0-10000)

-8 Don't know

-9 Refused

Question PRO. Which of the following products were sold by your company in 2005? (INT: READ LIST)

Live plants

Horticultural supplies such as fertilizer, chemicals, seeds, pots and soil

Horticultural hard goods (tools, irrigation parts,

lawnmowers, etc)

Other (please specify)

Don't know

Refused 
Question SALES7. Next, I am going to ask you what percentage each of the products you selected made up your total sales last year. Your total percentage of ALL of the products should add up to 100 percent. (INT: PRESS 1 TO CONTINUE)

Question PRO1. That's \% so far. What was the percentage of your total 2005 sales for

(0-100)

-8 Don't know

-9 Refused

Question OVER100G. The total of the percentages you gave is \%. Would you like to change any of your answers? (INT: If respondent says yes, go back and change any answers the respondent wants to change. If the respondent says no, press 1to continue)

Question CUST2. Which of the following types of customers were your products sold to in 2005? (INT:

READ LIST)

Homeowners

Apartments and condominiums

Commercial establishments (restaurants, hotels, office buildings, etc.)

Governments

Landscapers, interiorscapers or lawn maintenance firms

Other retailers

Other type of customer (please specify)

Don't know

Refused

Question SALES8. Next, I am going to ask you what percentage each of the customer types you selected made up your total sales last year. Your total percentage of ALL of the customer types should add up to 100 percent. (INT: PRESS 1 TO CONTINUE)

Question ZZ. That's \% so far. What was the percentage of your total 2005 sales to

$(0-100)$

-8 Don't know

-9 Refused

Question OVER100H. The total of the percentages you gave is \%. Would you like to change any of your answers? (INT: If respondent says yes, go back and change any answers the respondent wants to change. If the respondent says no, press 1 to continue)

Question FIELD. What was the net area, in acres, used by your business in 2005 for field (in ground) plant production?

(0-10000)

-8 Don't know

-9 Refused

Question EMPLOYEE. How many permanent full-time employees were employed by your business in 2005, including management and family members working in the business?

(0-999)

-8 Don't know

-9 Refused

Question PARTTIME. How many additional temporary or part-time employees were employed by your

business in 2005?

(0-999)

-8 Don't know

-9 Refused

Question RN. Which of the following services were

offered by your company in 2005?

Landscape design or consulting

Landscape installation

Landscape maintenance

Other service (please specify)

Don't know

Refused

Question SALES3. Next, I am going to ask you what percentage each of the services you selected made up your total sales last year. Your total percentage of ALL of the services should add up to 100 percent. (INT: PRESS 1 TO CONTINUE)

Question AC. That's \% so far. What was the percentage of your total 2005 sales for

$(0-100)$

-8 Don't know

-9 Refused

Question OVER100C. The total of the percentages you gave is \%. Would you like to change any of your answers? (INT: If respondent says yes, go back and change any answers the respondent wants to change. If the respondent says no, press 1 to continue)

Question CC. Which of the following types of customers were your products sold to in 2005? (INT:

READ LIST)

Homeowners

Apartments and condominiums

Commercial establishments (restaurants, hotels, office buildings, etc.)

Governments

Builders or developers

Other landscapers or lawn maintenance firms

Other (please specify)

Don't know

Refused

Question SALES4. Next, I am going to ask you what percentage each of the customer types you selected made up your total sales last year. Your total percentage of ALL of the customer types should add up to 100 percent. (INT: PRESS 1 TO CONTINUE) 
Question JZ. That's \% so far. What was the percentage of your total 2005 sales to (0-100) -8 Don't know -9 Refused

Question OVER100D. The total of the percentages you gave is \%. Would you like to change any of your answers? (INT: If respondent says yes, go back and change any answers the respondent wants to change. If the respondent says no, press 1 to continue)

Question RM1. Which of the following geographic regions were your products sold to in 2005? (INT:

READ LIST)

Local area - the city or county, or within a radius of 50 miles

Florida - but outside local area

Southeast states - except Fla

Other states

Foreign countries

Don't know

Refused

Question SALES6. Next, I am going to ask you what percentage each of the regions you selected made up your total sales last year. Your total percentage of ALL of the regions should add up to 100 percent. (INT: PRESS 1 TO CONTINUE)

Question GR1. That's \% so far. What was the percentage of your total 2005 sales to

-8 Don't know

-9 Refused

Question OVER100F. The total of the percentages you gave is \%. Would you like to change any of your answers? (INT: If respondent says yes, go back and change any answers the respondent wants to change. If the respondent says no, press 1 to continue)

Question AD. Which of the following types of ornamental plants were grown or marketed by your company in 2005? (INT: READ LIST)

Deciduous shade trees

Shrubs

Flowering and fruit trees

Evergreen trees

Palms

Tropical foliage

Vines and ground covers

Potted flowering plants and bedding plants

Cut foliage or flowers

Propagating liners, cuttings, or plugs

Turfgrass

Other (please specify)

Don't know

Refused
Question SALES. Next, I am going to ask you what percentage each of the plants you selected made up your total sales last year. Your total percentage of ALL of the plants should add up to 100 percent. (INT: PRESS 1 TO CONTINUE)

Question WM. That's \% so far. What was the percentage of your total 2005 sales for

(0-100)

-8 Don't know

-9 Refused

Question OVER100. The total of the percentages you gave is \%. Would you like to change any of your answers? (INT: If respondent says yes, go back and change any answers the respondent wants to change. If the respondent says no, press 1 to continue)

Question NATIVE. What percentage of your total sales in 2005 were Florida native plants, (defined as plants present in Florida prior to European settlement)?

(0-100)

-8 Don't know

-9 Refused

Question SERVICES. Which of the following services were offered by your company in 2005? (INT: READ CHOICES)

Contract growing

Delivery

Mail order

Horticultural consulting

Landscape design

Landscape installation

Landscape maintenance

Other service (please specify)

Don't know

Refused

Question JB. Which of the following types of customers were your products sold to in 2005? (INT:

READ LIST)

Other growers

Re-wholesalers or brokers

Landscape contractors

Interiorscapers

Landscape maintenance firms

Independent retail garden centers

Mass merchandise stores

Home improvement centers

Supermarkets

Developers or property managers

Direct to the public

Other type of customer (please specify)

Don't know

Refused

Question SALES1. Next, I am going to ask you what percentage each of the customer types you selected made up your total sales last year. Your total percentage 
of ALL of the customer types should add up to 100 percent. (INT: PRESS 1 TO CONTINUE)

Question JD. That's \% so far. What was the percentage of your total 2005 sales to

$(0-100)$

-8 Don't know

-9 Refused

Question OVER100A. The total of the percentages you gave is \%. Would you like to change any of your answers? (INT: If respondent says yes, go back and change any answers the respondent wants to change. If the respondent says no, press 1 to continue).

Question CUSTTYPE. Which of these customer types do you consider to be expanding? (INT: READ LIST)

Other growers

Re-wholesalers or brokers

Landscape contractors

Interiorscapers

Landscape maintenance firms

Independent retail garden centers

Mass merchandise stores

Home improvement centers

Supermarkets

Developers or property managers

Direct to the public

Other type of customer (please specify)

Don't know

Refused

Question RM. Which of the following geographic regions were your products sold to in 2005? (INT:

READ LIST)

Local area - the city or county, or within a radius of 50 miles

Florida - but outside local area

Southeast states except Fla.

Northeast states

Midwest states

Western states

Canada

Other foreign countries (except Canada) (please specify)

Don't know

Refused

Question SALES2. Next, I am going to ask you what percentage each of the regions you selected made up your total sales last year. Your total percentage of ALL of the regions should add up to 100 percent. (INT:

PRESS 1 TO CONTINUE)

Question GR. That's \% so far. What was the percentage of your total 2005 sales to

(0-100)

-8 Don't know

-9 Refused
Question OVER100B. The total of the percentages you gave is \%. Would you like to change any of your answers? (INT: If respondent says yes, go back and change any answers the respondent wants to change. If the respondent says no, press 1 to continue).

Question PRACTICE. Which of the following

marketing practices does your company use to sell your products? (INT: READ CHOICES)

Personal selling by telephone or personal visit Commissioned salesperson

Promotions such as price discounts or special services offered

Trade shows

Direct mail advertising

Trade magazine advertising

Printed advertising media for public such as

magazines,newspapers,brochures

Radio or television advertising

Computer website

Participation in civic events and making charitable contributions

Other practice (please specify)

Don't know

Refused

Question GROSS. What was your company's gross

sales in 2005?

1 less than $\$ 100$ thousand

$2 \$ 100$ to $\$ 249$ thousand

$3 \$ 250$ to $\$ 499$ thousand

$4 \$ 500$ to $\$ 999$ thousand

$5 \$ 1$ to $\$ 2.4$ million

$6 \$ 2.5$ to $\$ 4.9$ million

$7 \$ 5$ to $\$ 9.9$ million

$8 \$ 10$ to $\$ 14.9$ million

$9 \$ 15$ to $\$ 24.9$ million

$10 \$ 25$ million or more

-8 Don't know

-9 Refused

Question GROSSM. Please specify amount to nearest $\$ 1$ million.

(25-100)

-8 Don't know

-9 Refused

Question THREATS. Rate the following threats facing your industry as either very important, somewhat important, or not important. (INT: PRESS 1 TO CONTINUE)

Question DH. How important is this threat to your industry?

1 Very important

2 Somewhat important

3 Not important

-8 Don't know

-9 Refused 
Question PSKIP. How important is this threat to your industry?

1 Very important

2 Somewhat important

3 Not important

-8 Don't know

-9 Refused

Question THREATS1. Rate the following threats facing your industry as either very important, somewhat important, or not important. (INT: PRESS 1 TO CONTINUE)

Question DH1. How important is this threat to your industry?

1 Very important

2 Somewhat important

3 Not important

-8 Don't know

-9 Refused

Question HSKIP. How important is this threat to your industry?

1 Very important

2 Somewhat important

3 Not important

-8 Don't know

-9 Refused

Question BORROW. Does your business borrow money from financial lenders?

1 Yes

2 No

-8 Don't know

-9 Refused

Question FINANCE. What are the financial institutions you currently use for borrowing money for your business? You can tell me up to three names, and please give them in the order of importance.

(Most important)

(Second most important)

(Third most important)

Don't know

Refused

Question REASONS. Why did you choose your primary financial institution as your business lender?

(INT: READ CHOICES)

Competitive interest rates

Convenient or flexible repayment terms

Knowledge of the industry

Operates like a cooperative

Long term or personal relationship with lender representative

Other (please specify)

Don't know

Refused
Question SATIS. How satisfied are you with your primary financial lender? (INT: READ LIST)

1 Very satisfied

2 Somewhat satisfied

3 Neither satisfied nor dissatisfied

4 Somewhat dissatisfied

5 Very dissatisfied

-8 Don't know

-9 Refused

Question CREDIT. In the next year, do you expect your credit needs to increase, decrease or remain the same as the past year?

1 Increase

2 Decrease

3 Remain the same

-8 Don't know

-9 Refused

Question CREDITCH. By what percentage do you expect your credit needs to change?

(0-100)

-8 Don't know

-9 Refused

Question BANKING. Do you currently use some type of electronic banking?

1 Yes

2 No

-8 Don't know

-9 Refused

Question LOAN. Would you consider applying for a business loan electronically on the internet?

1 Yes

2 No

-8 Don't know

-9 Refused

Question HURR. Did your company suffer any crop losses, structural damages cleanup costs, or business interruption due to hurricanes in 2004 or 2005 ?

1 Yes

2 No

-8 Don't know

-9 Refused

Question HURR1. Which of the following named hurricanes affected your business? (INT: READ CHOICES)

Charley (Aug 2004)

Frances (Early Sep 2004)

Ivan (Mid Sep 2004)

Jeanne (Late Sep 2004)

Dennis (July 2005)

Katrina (Aug 2005)

Rita (Aug 2005)

Wilma (Oct 2005)

Don't know

Refused 
Question HURR2004. How many hurricanes affected your business in 2004?

(0-4)

-8 Don't know

-9 Refused

Question HURR2005. How many hurricanes affected your business in 2005?

$(0-4)$

-8 Don't know

-9 Refused

Question HURR2. What was the approximate total value of ornamental crops lost due to the hurricane(s) in 2004 and 2005?

0 None (not applicable)

1 Less than \$1 thousand

$2 \$ 1$ to $\$ 9$ thousand

$3 \$ 10$ to $\$ 99$ thousand

$4 \$ 100$ to $\$ 499$ thousand

$5 \$ 500$ to $\$ 999$ thousand

6 \$1 million or more

-8 Don't know

-9 Refused

Question HURRM1. Please specify amount to nearest one-tenth million dollars. (INT: Read if needed: One million one hundred thousand dollars would be 1.1 million.)

$(0.0-100.0)$

-8 Don't know

-9 Refused

Question HURR3. What was the approximate total value of structural damage due to the hurricane(s) in 2004 and 2005, including greenhouses, shadehouses, other buildings, irrigation systems and other equipment?

0 None (not applicable)

1 Less than $\$ 1$ thousand

$2 \$ 1$ to $\$ 9$ thousand

$3 \$ 10$ to $\$ 99$ thousand

$4 \$ 100$ to $\$ 499$ thousand

$5 \$ 500$ to $\$ 999$ thousand

$6 \$ 1$ million or more

-8 Don't know

-9 Refused

Question HURRM2. Please specify amount to nearest one-tenth million dollars. (INT: Read if needed: One million one hundred thousand dollars would be 1.1 million.)

$(0.0-100.0)$

-8 Don't know

-9 Refused

Question HURR4. What was the approximate total value of cleanup costs due to the hurricane(s) in 2004 and 2005?
0 None (not applicable)

1 Less than $\$ 1$ thousand

$2 \$ 1$ to $\$ 9$ thousand

$3 \$ 10$ to $\$ 99$ thousand

$4 \$ 100$ to $\$ 499$ thousand

$5 \$ 500$ to $\$ 999$ thousand

6 \$1 million or more

-8 Don't know

-9 Refused

Question HURRM3. Please specify amount to nearest one-tenth million dollars. (INT: Read if needed: One million one hundred thousand dollars would be 1.1

million.)

$(0.0-100.0)$

-8 Don't know

-9 Refused

Question HURR5. How long was your business interrupted by the hurricanes in 2004 and 2005? (INT: If the respondent gives an answer that does not fit one of the categories, read the list)

1 Not at all

2 A few days

31 to 2 weeks

43 to 4 weeks

52 to 3 months

64 months or more

-8 Don't know

-9 Refused

Question ELSE. Do you have any additional comments about how your business affects the economy?

1 Has answer

2 No (none)

-8 Don't know

-9 Refused

Question THANKYOU. That is the end of the survey. Thank you for your time and cooperation. (INT: PRESS G TO END THE SURVEY. DO NOT PRESS CTRL END) 